\title{
Research Paper \\ Comparison of the Effectiveness of Mindfulness-Based Cognitive Therapy and Emotion Regulation Training on Parental Stress of Mothers with Aggressive Children
}

\author{
Afsaneh Shokri ${ }^{1}$, Reza Kazemi" ${ }^{* 2}$, Mohammad Narimani ${ }^{3 \& 4}$, Somayeh Taklavi ${ }^{2}$ \\ 1. Ph.D. Student of Psychology, Ardabil Branch, Islamic Azad University, Ardabil, Iran \\ 2. Assistant Professor, Department of Psychology, Ardabil Branch, Islamic Azad University, Ardabil, Iran \\ 3. Professor, Department of Psychology, Ardabil Branch, Islamic Azad University, Ardabil, Iran \\ 4. Professor, Department of Psychology, Faculty of Psychology and Educational Sciences, University of Mohaghegh Ardabili,
} Ardabil, Iran

Citation: Shokri A, Kazemi R, Narimani M, Taklavi S. Comparison of the effectiveness of mindfulness-based cognitive therapy and emotion regulation training on parental stress of mothers with aggressive children. Quarterly Journal of Child Mental Health. 2020; 7(1): 205-219.

\section{http://dx.doi.org/10.29252/jcmh.7.1.18}

\section{A R T I C L E I N F O}

\section{Keywords:}

Aggression,

Mindfulness-based

Cognitive Therapy, emotion regulation training, parental stress

Received: 10 Dec 2019 Accepted: 15 Mar 2020 Available: 20 Jun 2020
A B S T R A C T

Background and Purpose: Aggression is one of the major problems in schools. Family members, especially mothers play an important role in the development of aggressive behaviors in children. The purpose of this study was to compare the effectiveness of mindfulness-based cognitive therapy and emotion regulation training on parental stress of mothers with aggressive children.

Method: This study was an experimental research with pretest-posttest control group design. The population included all the female students studying at the primary schools of Namin city in the academic year of 2018-2019 ( $\mathrm{N}=540)$ together with their mothers. Totally, 217 students as the initial sample were selected by multi-stage clustering sampling and the aggression questionnaire was completed for them by the teachers. Finally, considering the inclusion criteria, mothers of 60 aggressive student were selected as the study sample and randomly assigned to any of the three groups ( $\mathrm{n}=20$ per group). Data were collected by Shahim's Aggression Scale (Shahim, 2006) and Parenting Stress Questionnaire (Abidin, 2016) and analyzed by ANCOVA through using SPSS Version 20.

Results: Data analysis showed that both mindfulness-based cognitive therapy and emotion regulation training were effective in decreasing the parental stress of mothers with aggressive children. Also, mindfulness-based cognitive therapy was more effective in decreasing the parental stress of mothers with aggressive children in comparison to emotion regulation training $(\mathrm{p}<0.05)$.

Conclusion: Considering the higher effectiveness of mindfulness-based cognitive therapy on parental stress, it can be concluded that through techniques such as paying attention to breathing and body and turning awareness here and now, mindfulness affects the cognitive system and information processing and reduces mental rumination and dysfunctional attitudes in people, and these changes can reduce parental stress.

\footnotetext{
* Corresponding author: Reza Kazemi, Assistant Professor, Department of Psychology, Ardabil Branch, Islamic Azad University, Ardabil, Iran. E-mail addresses: Dr_reza.kazemi@yahoo.com
} 


\section{مقايسه اثربخشى شناختدرمانى مبتنى بر ذهن آكاهى و آموزش تنظيم شناختى هيجان

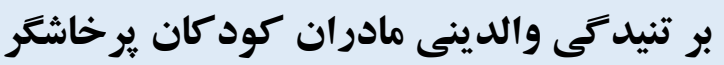

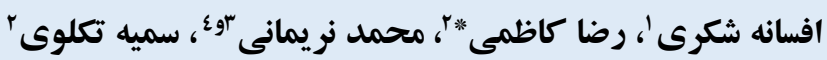

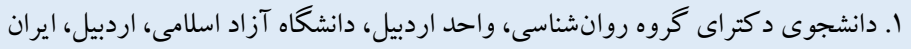

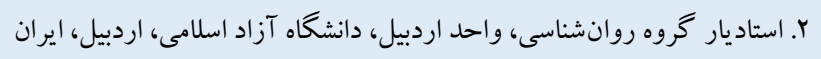

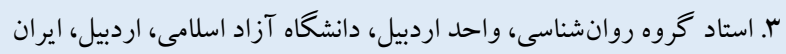

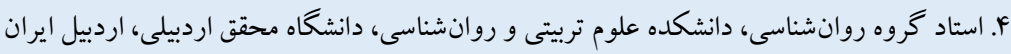

جكيده

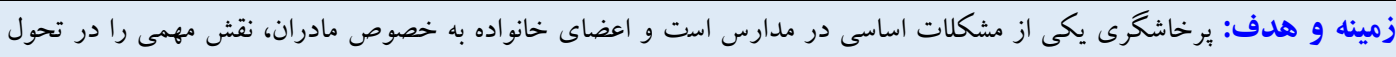

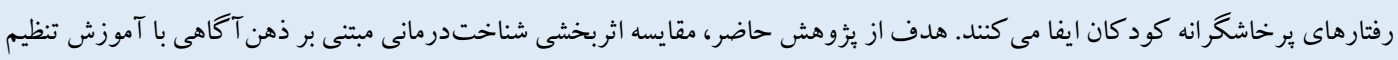

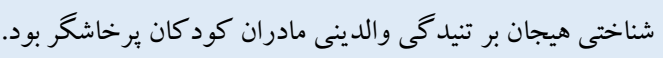

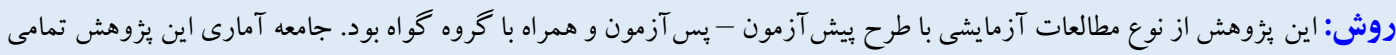

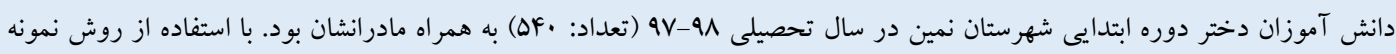

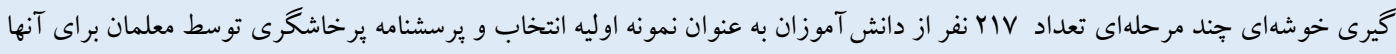

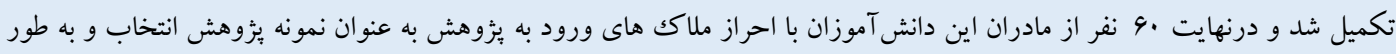

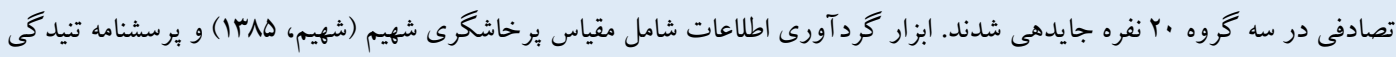

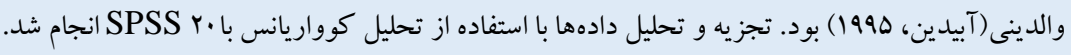

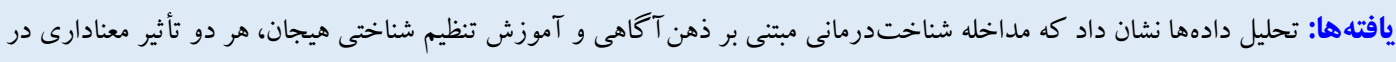

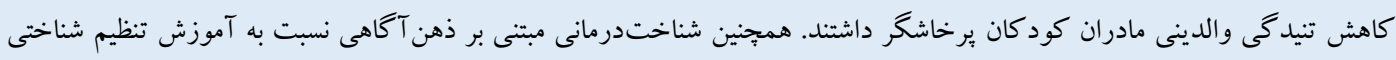

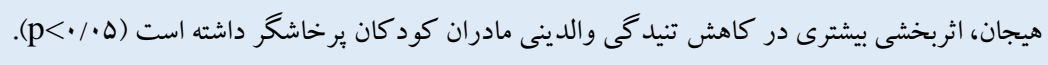

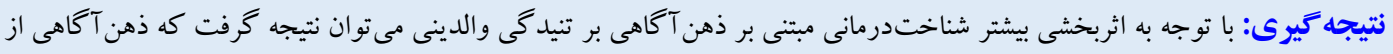

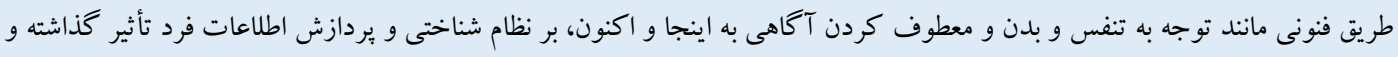

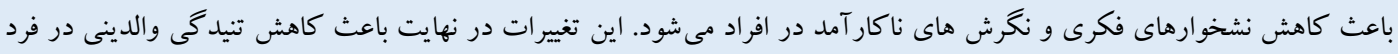

مشخصات مقاله

كليدوازهها:

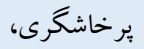

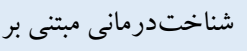

ذهن آكاهى،

آموزش تنظيم شناختى هيجان،

تنيدگى والدينى

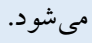

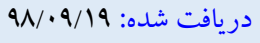

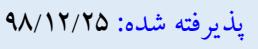

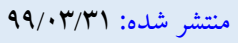

* نويسنده مسئول: رضا كاظمى، استاديار گروه روانشناسى، واحد اردبيل، دانشكاه آزاد اسلامى، اردبيل، ايران.

رايانامه: Dr_reza.kazemi@yahoo.com

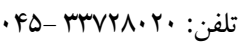


ادراكى والدين از سطح تنيدگى مزمن ناشى از بزرگك كردن فرزندان

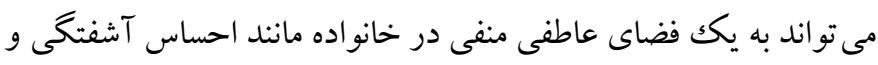

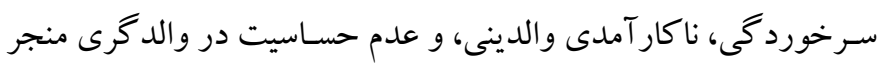

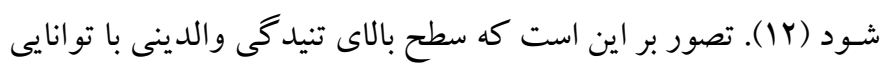

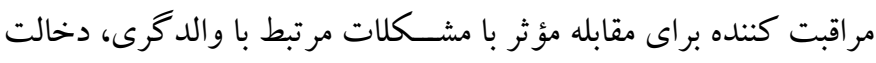

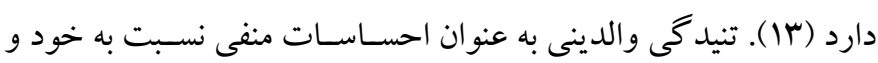

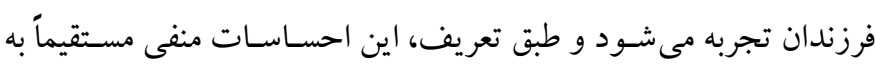

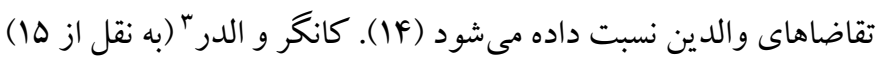

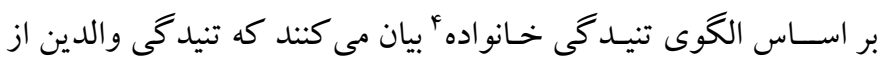

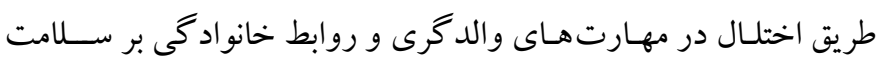

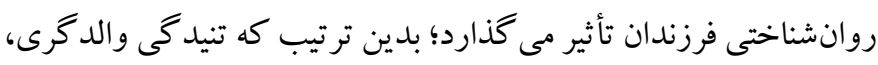

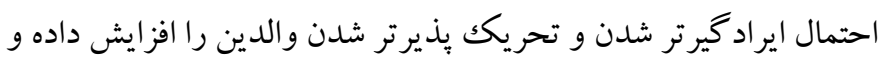

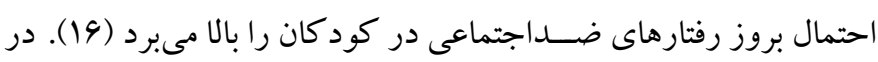
مطالعات بسيارى نشـان داده شـده اسـت كه والدين كود كان با اختلالات

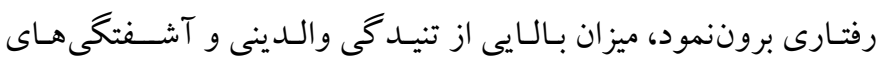

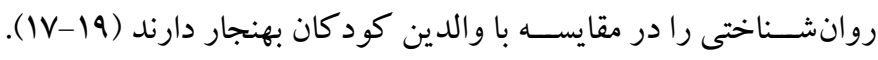
بــدين ترتيـب براسـاس اين مطـالعات، تعامل منفى مادر - كود كك عامل

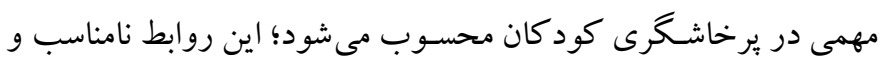

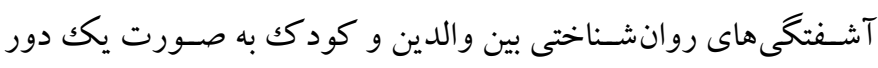

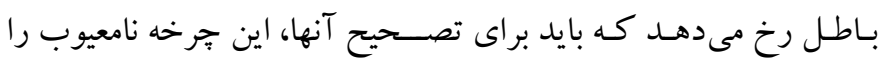

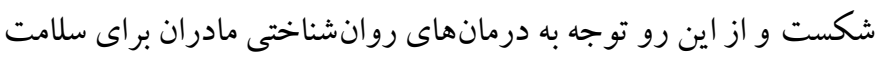

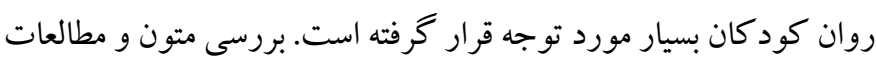

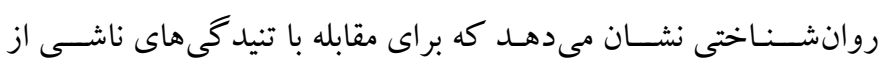

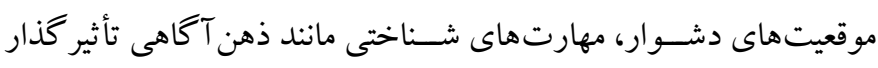

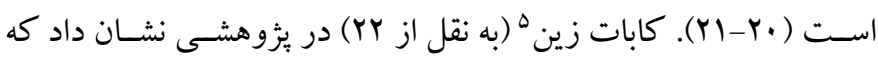

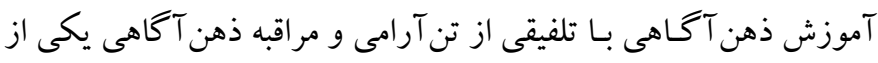

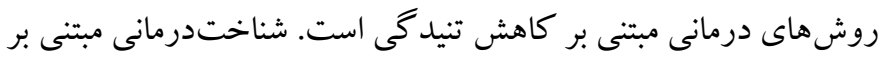

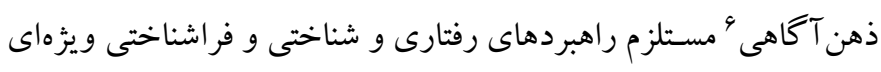

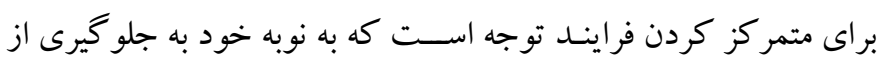

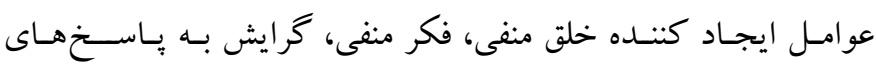

4. Family Stress Model (FSM)

5. Kabbat Zin

6. Mindfulness-based cognitive therapy

مقام

كود كان قشر عمدهاى از جمعيت جهان را تشكيل مىدهند. در كشورهاى در حال توسعه سهم كود كان از كل جمعيت تقريباً به هله درصد مى مىرد (1). دور ان كودكى از مهم ترين مراحل زندكى است كه در آن شخصيت فرد يايهريزى شده و شكل مى گيرد. اغلب اختلالات و سازشنايافتخى هاى رفتارى يس از دوران كودكى ناشـى از كمبود توجه به دوران حســاس كودكى و عسدم هـدايست صـسحيح در رونسـ تحول كودكك اســت. اين بى توجهى منجر بـه عـدم ســازش و انطبـاق بـا محيط و بروز انحر افـات كوناگون در ابعاد مختلف براى كودكك مىشـود (Y). كود كان در مقطع ابتدايى با مشكلات متعددى مانند اختلالات هيجانى رفتارى مواجه هستند. شــيوع اختلالات رفتارى در كود كان ايرانى سب درصــد اســت (ب). اين مشكلات در كود كان دبستانى منجر به بروز اختلالاتى مانند سطح بالايى از

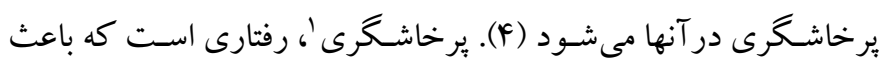
تهديد و احتمالاً آسـيب مى شـود و ممكن اسـت كلامى (مانند تهديد) يا

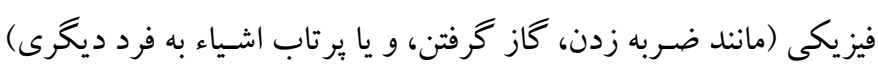
بـاشــــ. محيط خانواده نقش مهمى را در تحول رفتارهاى برخاشـــر انه

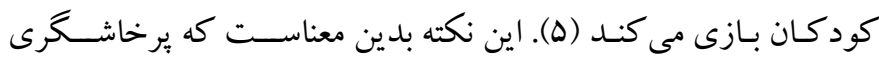
كود كك ممكن است تا حدودى ناشى از عو امل مر تبط با خانو اده همجيون تعارضات والدينى در شيوههاى والدكرى، مشكلات روانى، و يرخاشخرى والـدين (4-4) و نـاتوانى والدين در مديريت رفتار كودكك، تعامل منفى والـد-كودك،، و نيز تنيـدگى والـدينى ب بـاشــــ (9). آبيـدين تنيـدكى والدگرى را حاصل اثر تعاملى خصوصيات والدين (سلامت روانشناختى،

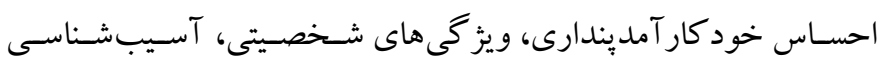
روانى) و ويز كى هاى فرزندان (قدرت انطباقيذيرى، مزاج، تقاضامندى) مىداند و مشكلات رفتارى فرزندان و تعاملات ناكار آمد والد-فرزندى را از منابع گسترده ايجاد تنيدگى در والدين و مختل كننده كاركرد خانواده

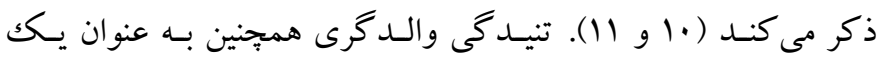
اختلاف دركك شـده بين خواسـتههاى موقعيتى و منابع شـخصسى مرتبط با نقش والدينى تعريف شده است (11).

1. Aggression

2. Parenting stress

3. Conger \& Elder 
مشكلات هيجانى را تجربه مى كنتـد در مقابله با ايفاى نقش والدينى، ضعف نشان مىدهند و درنتيجه در تربيت كودكان با مشكلاتى مواجه

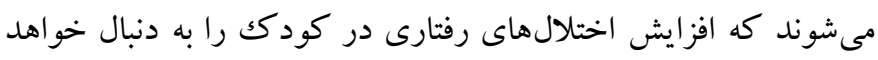

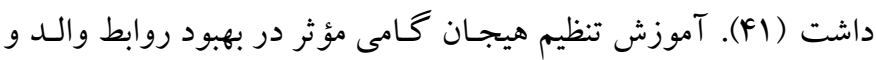
كودك بوده (4) و موجب كاهش استفاده از راهبردهاى منفى هيجانى مورنى براى مقابله با شر ايط تنش آور در مادران مىشود (FF).

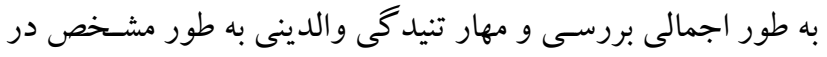

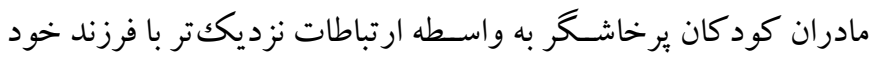
در ابعاد متفاوت شناختى و هيجانى، حائز اهميت است. بايد توجه داشت كه در اغلب بـرزوهشهـايى كه براى بررسى اثربخشى مداخلات درمانى

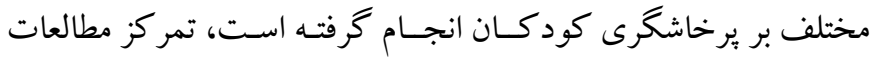

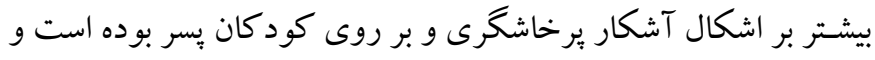

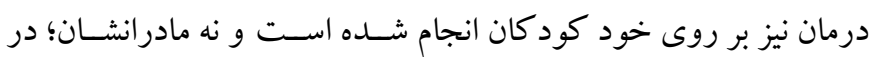

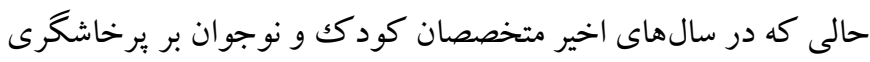

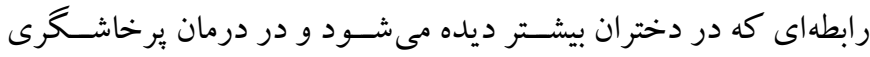
كود كان بر اقدامات بيشـيرانه و مداخلات تو انمندسـازى والدين، بيشتر

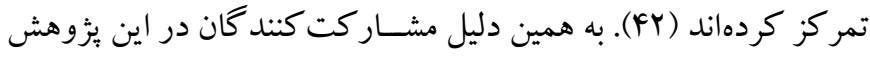

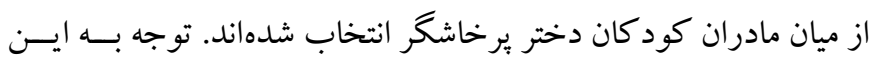

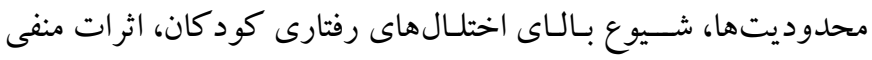
اختلالـات رفتـارى بر عملكرد فردى و خانوادگىى، نقش مادران در بروز

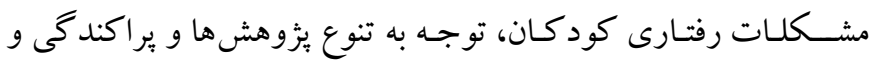

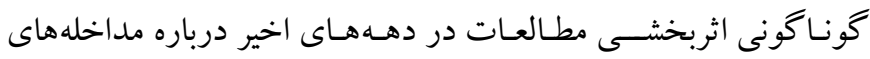

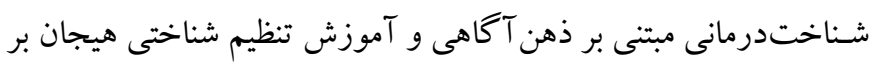

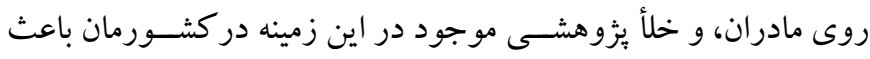
طرحريزى و اجراى اين مطالعه شده است. زيرا نتايج اين مطالعه مى تواند تلويحات نظرى و عملى مهمى درباره مؤثرترين درمانهاى حيطه سلامت

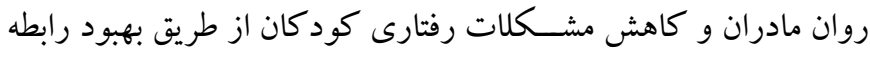

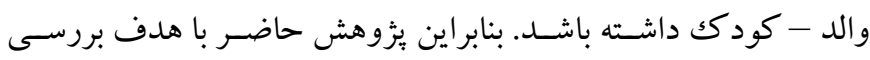

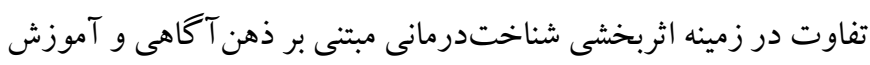
تنظيم شناختى هيجان بر كاهش تنيدگى والدگرى مادران داراى كود كى

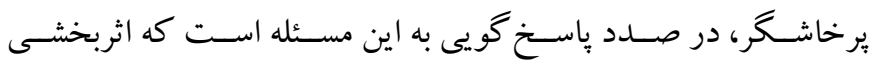

نخكران كننده و رشـــد ديد كاه جديد، و شــكل گيرى افكار و هيجانهاى خوشايند، منجر مى شود (r) ). ذهن آكاهى مى تواند با تنظيم توجه، توسعه

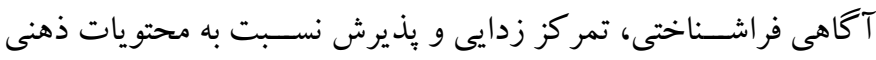
خود، در كاهش روانبنهاى سازشنايافته مؤثر باشد (YF). هدف اصلى

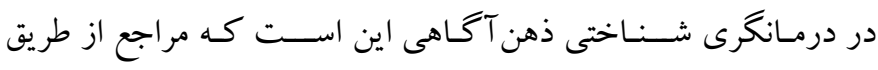

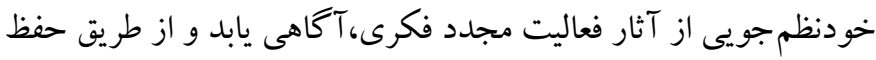

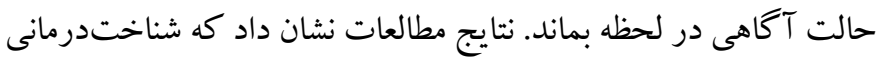

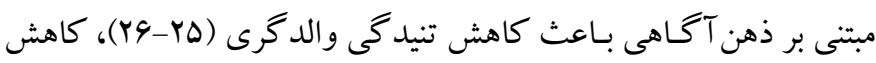

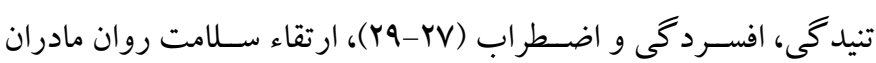

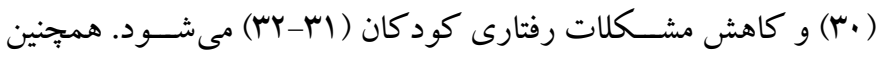
محمدى و همكاران نشـان دادند كه آموزش ذهن آكاهى مادران بهتر از

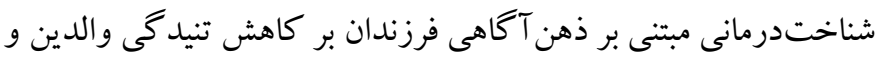
تعارض والد- نوجوان مؤثر است (سب).

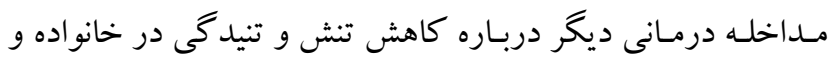

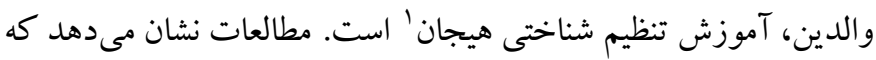

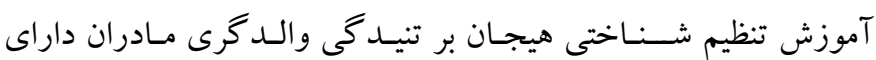

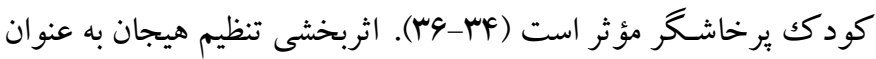

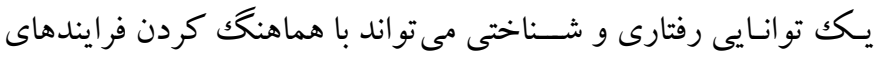

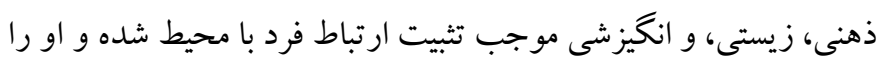

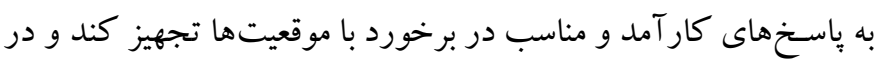
نتيجـه حس كـار آمـدى فرد را بهبود بخشــــ (TV). بسيارى از اختلالات كود كان از جمله اختلالهاى جسمانى، شناختى، رفتارى، و هيجانى تحت

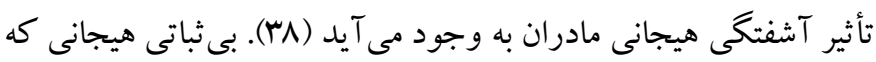

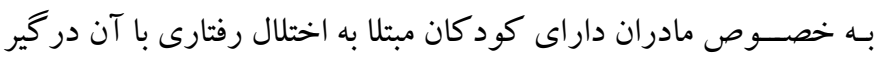
هستـند به خشـم نامناسـب، احسـاسـات مزمن، يوجى و نوسـان خلقى، و

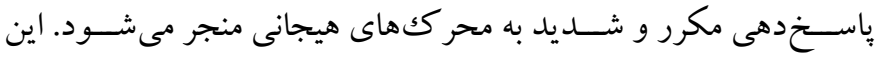

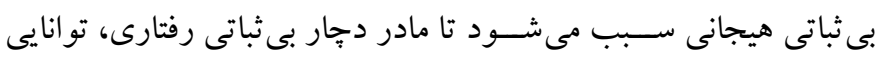

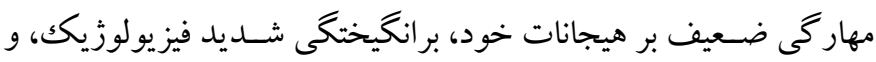

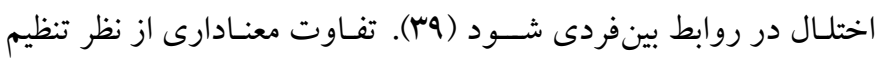

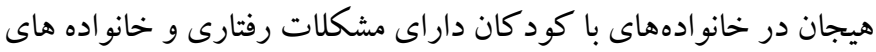

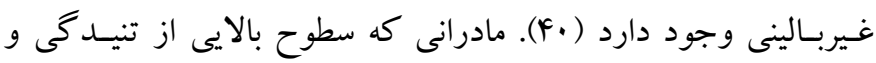


حداقل دو جلسه در جلسات آموزشسى و انجام ندادن تكاليف جلسـها

ا ـ مقياس يرخاشخحى رابطهاى و آشكار ': اين يرسشنامه توسط شهيم در

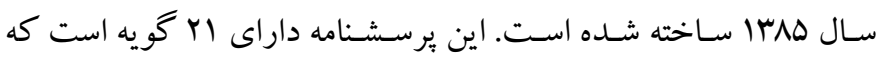

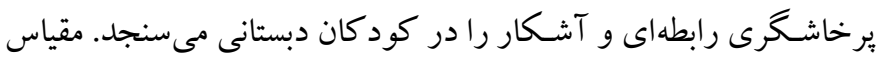

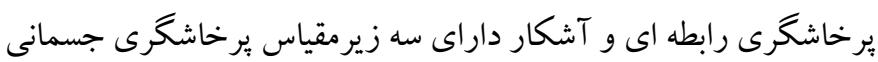

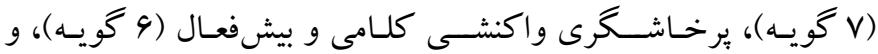

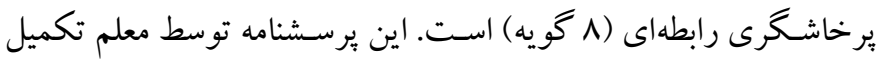

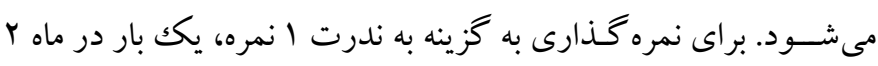

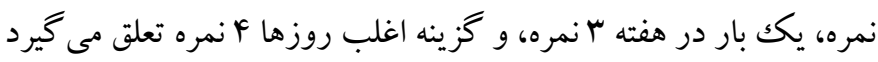

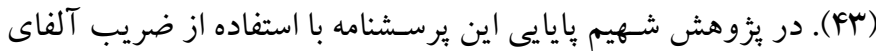

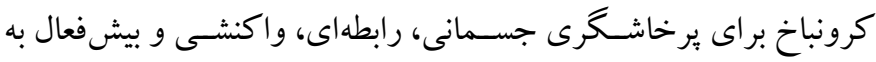

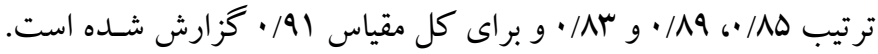
همجنين، ارزيابى روايى اين يرسشنامه با استفاده از تحليل عوامل با محور

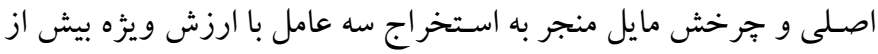

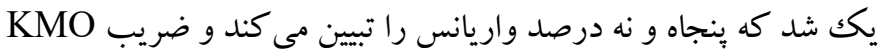

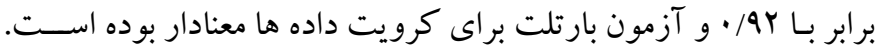

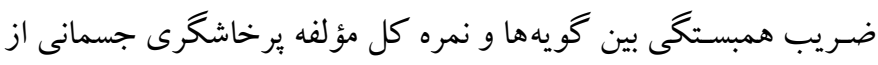

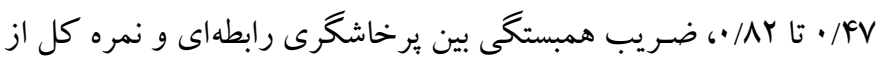

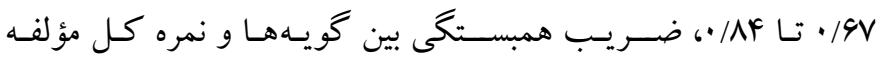

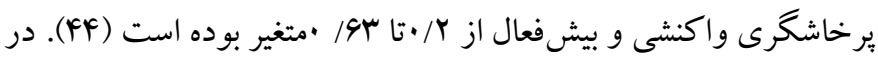
يزؤهش حاضـر ضـريب آلفاى كرونباخ براى كل مقياس Af/ • محاسـبه

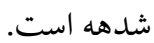
r. مقياس تنيدكى والدينى - فرم كوتاهّ'. اين مقياس توسـط آبيدين در

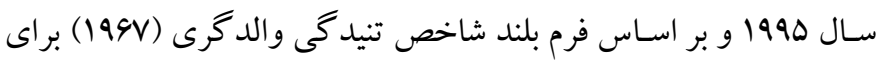

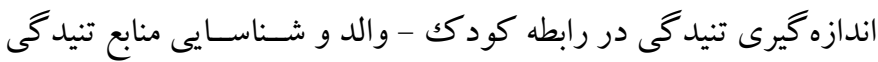
روانشـناختى آنها طراحى شـده اسـت. در اين ابزار، توصسيف رفتارهاى رئي

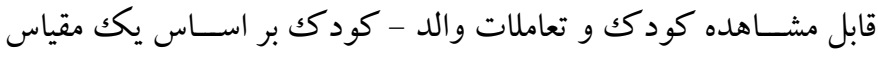

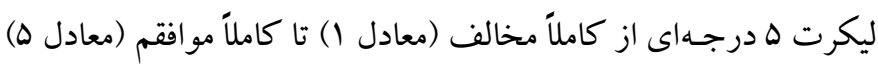

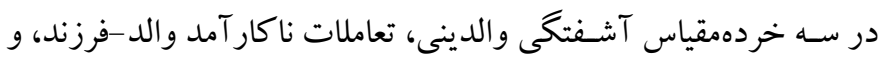

2. parental stress index (PSI) short form (SF)
شـناخت درمانى مبتنى بر ذهن آكاهى و آموزش تنظيم شناختى هيجان بر تنيدگى والدگرى جِكونه است؟

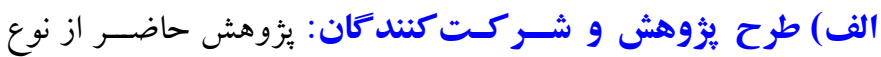

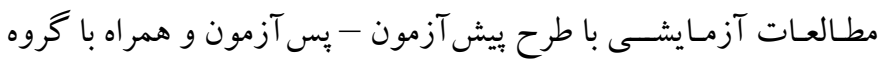

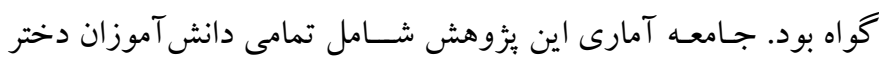

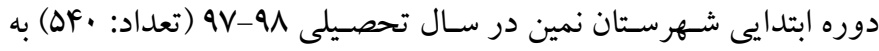

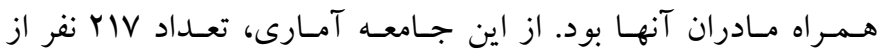

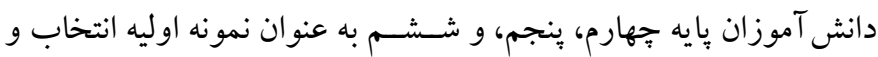
يرسشنامه ير خاشخرى شهيم توسط معلمان براى اين دانش آموزان تكميل

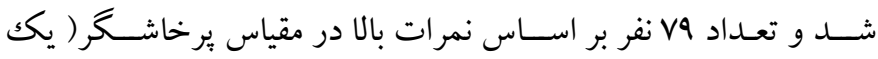

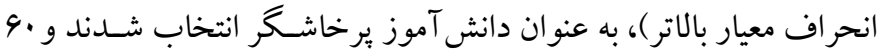

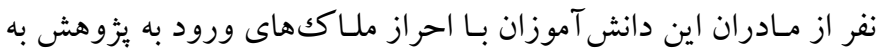

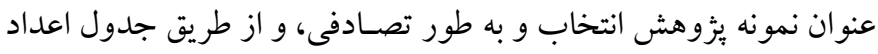

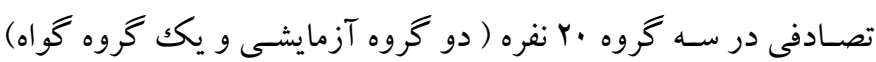

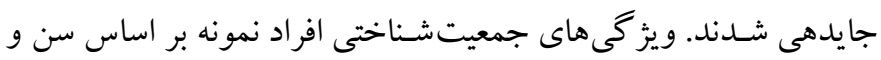
ميز ان تحصيلات بود و يافتهاى جمعيت شناختى نشان داد كه هه درصد

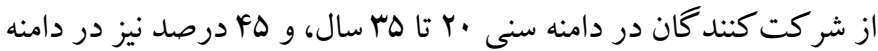

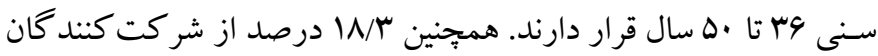

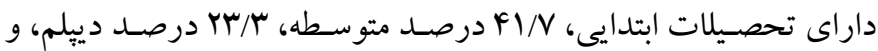
19/V درصــد نيز داراى تحصـيلات دانشــاهى بودند. ميانخين سـنى و

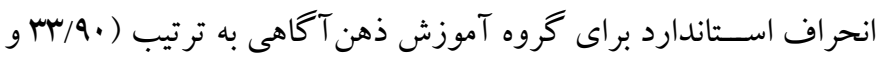

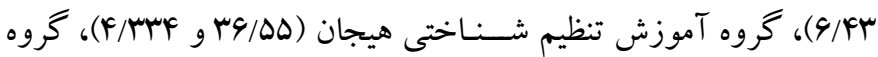

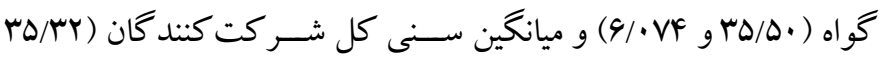
وه/99V) بود. ملـاككهـاى ورود اين يزوهش شــامل تمايل و رضـايت

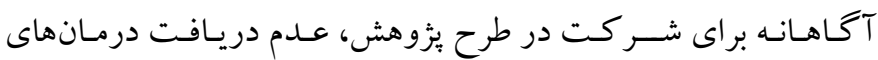

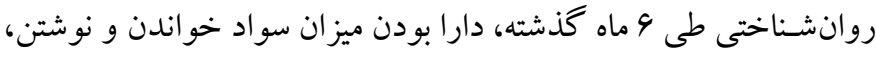

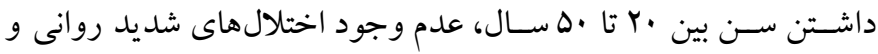

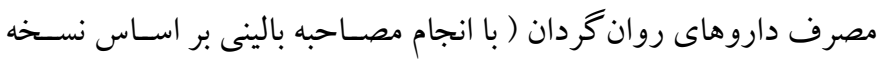
ينجم راهنماى تشخيصى و آمارى اختلالات روانى)، داشستن دانش آموز

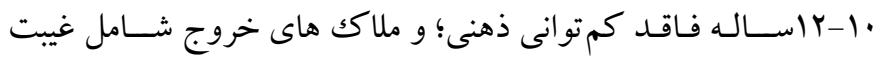

1. Overt and rrelational aggression questionnaire 
مر احل مداخله براســاس توصسيف عملى درمان شــناختى مبتنى بر

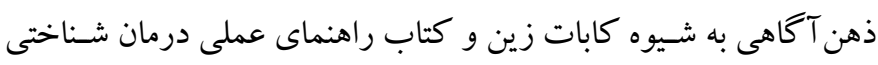

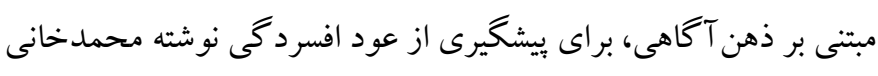

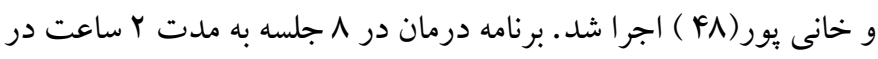
هفته و به شيوه گروهى انجام شد.

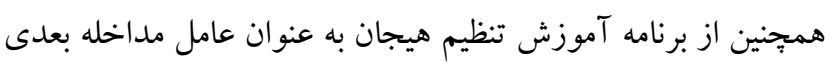

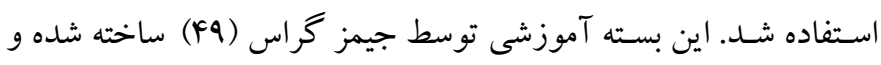

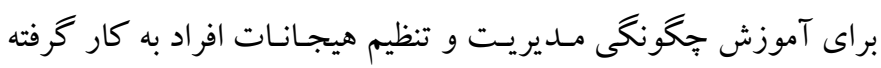

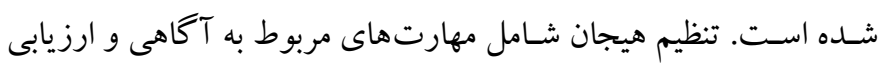

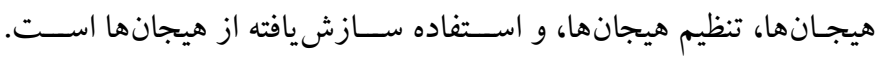

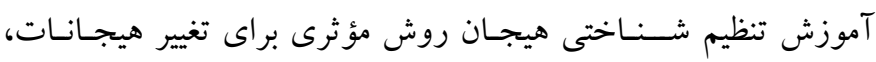

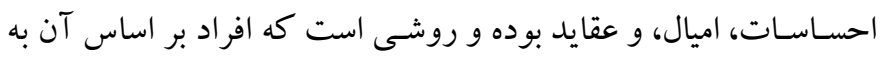

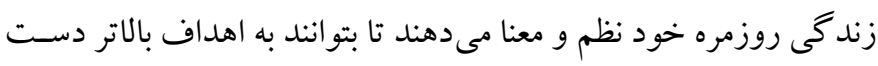
يابند. موفقيت افراد در رسـيدن به اهداف از طريق مهارت آنها در تنظيم

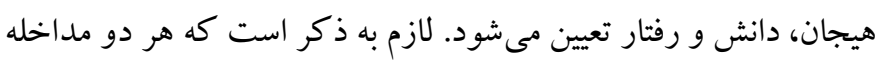

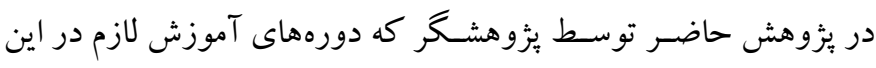

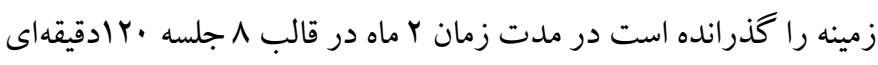
هفتهاى يكك روز (روزهاى دوشنبه شناختدرمانى مبتنى بر ذهن آكاهى و

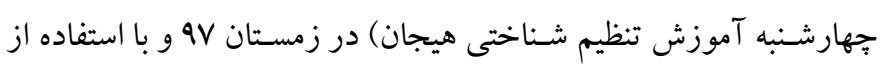

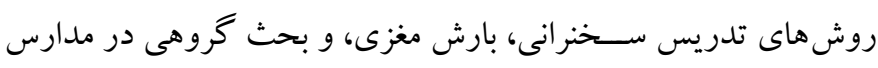

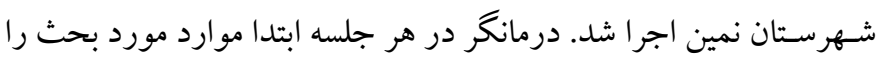

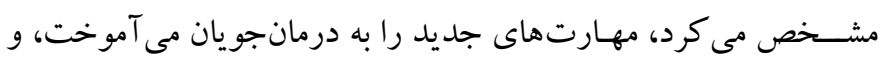
تكاليفى براى اجرا در فاصله بين جلسات معين شد. اين تكاليف بر اساس مداس ردان

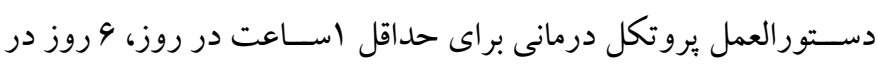

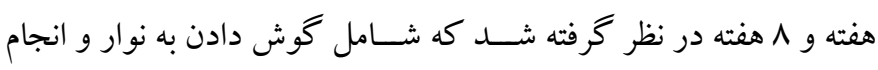

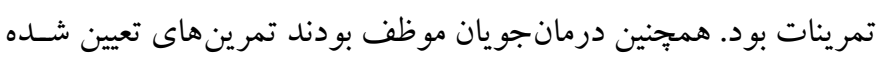

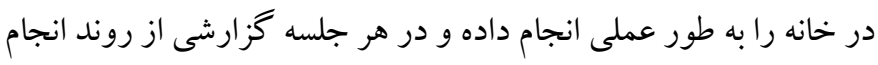

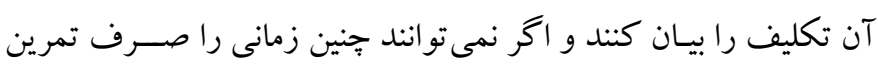

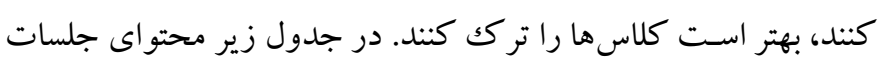
درمانى به اختصار ارائه شده است.
ويز گى هاى كود كك مشـكل آفرين، ارزيابى مى شـوند. دامنه نمر ات از وب

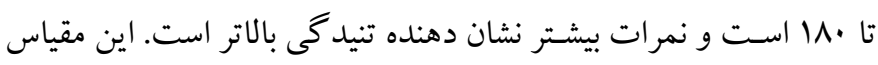

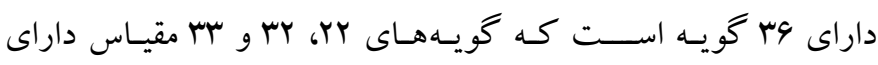

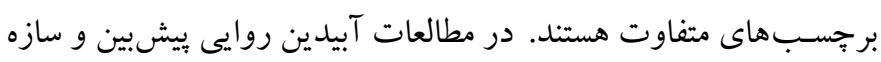

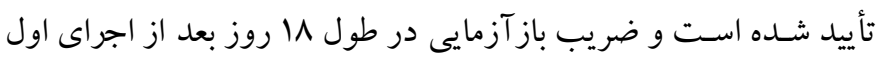

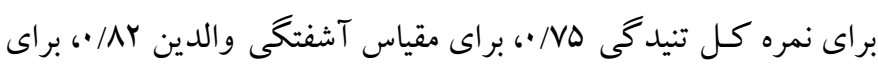

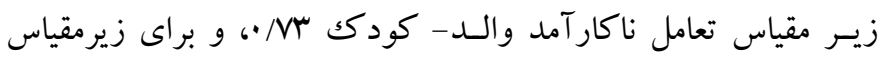

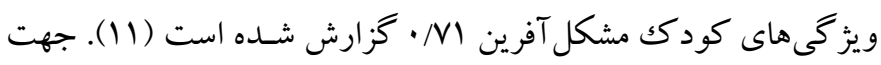
بررسـى روايى و بايايى نسـخه فارسـى اين ابزار نيز از روش هاى تحاى تحليل

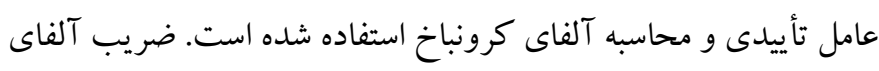

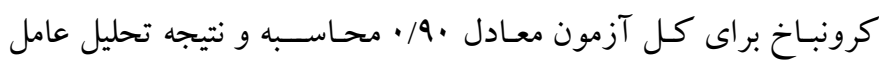

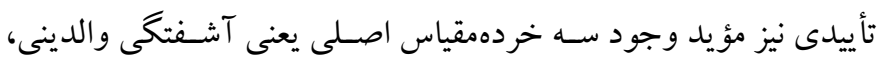

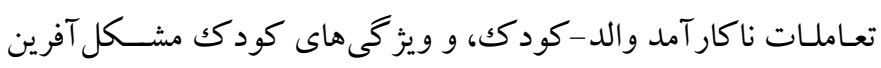

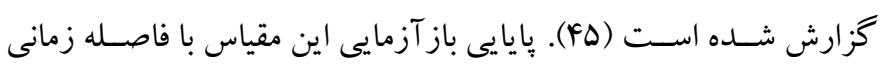

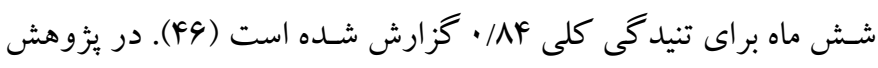

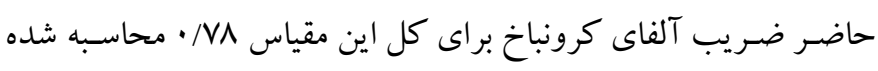
است. ج) معرفى برنـامه مداخلهاى: شــناخت درمانى مبتى بر ذهن آكاهى،

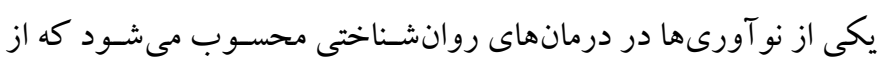

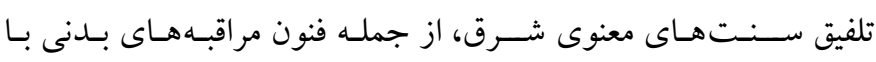

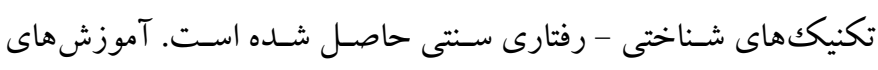

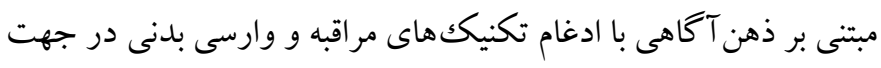

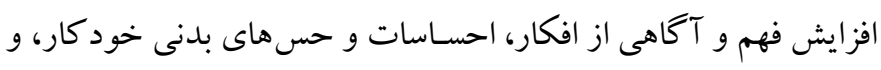

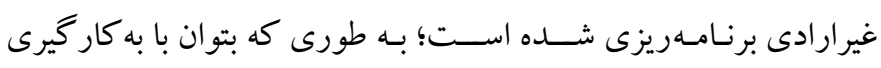

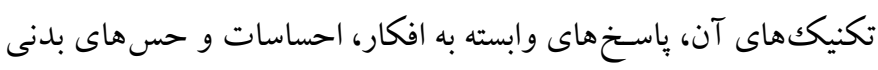

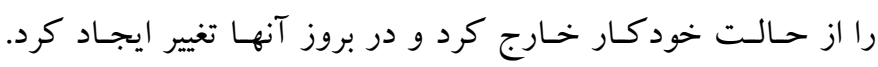

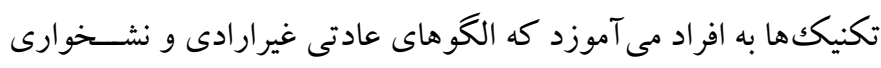

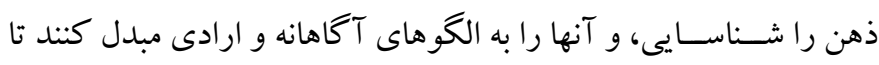

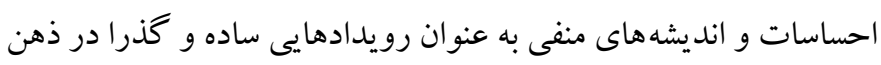
تلقى شوند (FV). (FV). 
جدول ا: محتواى جلسات درمانى

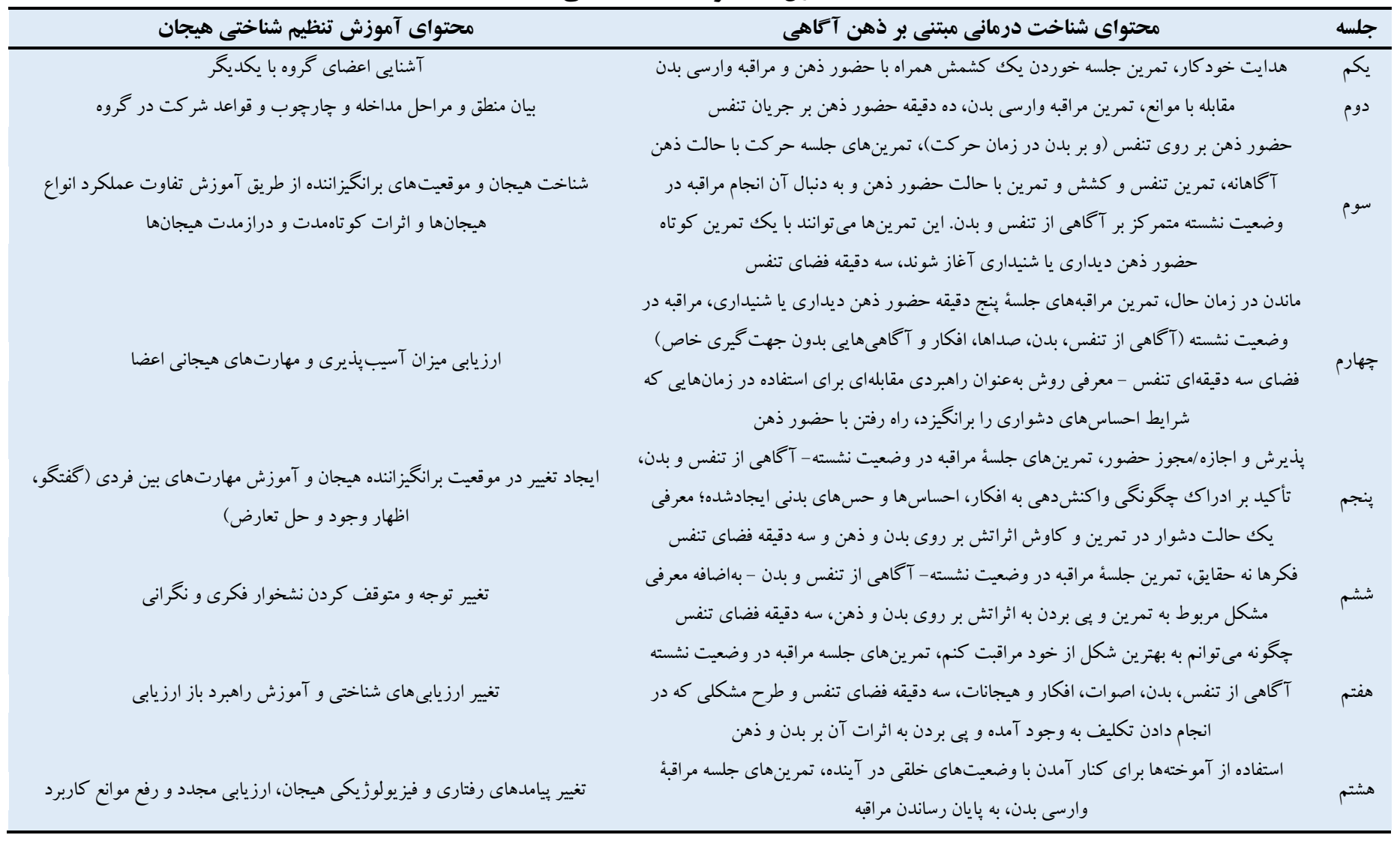

روشهـى درمـانى ^ جلســه · rا دقيقهاى بود و به صـورت گروهى و هفتهاى ا جلسـه، توسـط يثروهشـخر اجرا شــد. در طول اجراى جلسات آموزشى و درمانى، همسه آزمودنى هاى كروه آزمايشى حضور داشتند و هيج كدام از برنامه حذف نشدند. للازم به ذكر اسـت كه تمامى ملاحظات اخلاقى مانند رعايت اصـل رازدارى، محرمانه ماندن اطلاعات، و رضايت

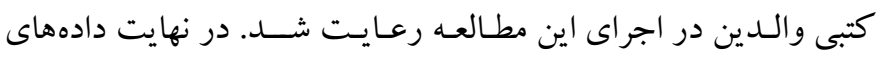

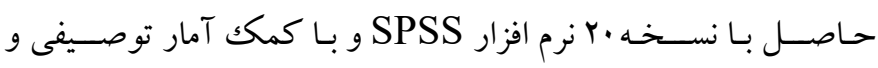
كواريانس جند متغيرى (مانكو ا) تحليل شدند.

\section{كافته ها}

در جدول Y شـاخصهاى توصسيفى متغيرهاى مورد مطالعه در گروههاى آزمايش و گواه و همجينين نتايج آزمون كالمو گروف اســميرنف جهت بررسى نرماليتى دادهها گزارش شده است.
د) روش اجرا: براى اجراى اين يزوهش بعد از كســب مجوزهاى للزم ابتـدا بز هشــكر در ســال تحصــيلى شـهرسـتان نمين مراجعه، و تعداد كل مدارس دخترانه ابتدايى و همجنين تعـداد دانش آموزان دختر در اين مـدارس را دريافت كرد. در مرحله بعد از روش خوشــهاى جنـدمرحلهاى براى تعيين دانش آموزان مورد مطالعه اسـتفاده شــد. بعد از انتخاب دانش آموزان مورد نظر، در ادامه از مادران اين دانش آموزان طى دعوتنامهاى درخواسـت حضــور در مدرسـهـ و كسـب رضـايت براى شـركت در جلسـات درمان و مصـاحبه اوليه براى بررسى ملاككهاى ورود به مطالعه، انجام شد. در نهايت ·9 نفر از مادران. دانش آموزان برخاشــر براى شركت در بزؤهش انتخاب شدند و در سه كروه جايدهى شـدند. لازم به ذكر اسـت كه همتاسـازى بين سه گرووه بر اســاس سـن و ميزان تحصــيـات انجام كرفت و با اســتفاده از تحليل كواريانس مورد بررسى قرار گرفت. مدت جلسات درمانى در هر يكك از 
جدول ب: آمارههاى توصيفى تنيدكى والدينى و مؤلفههاى آن در كروههاى آزمايش و كواه

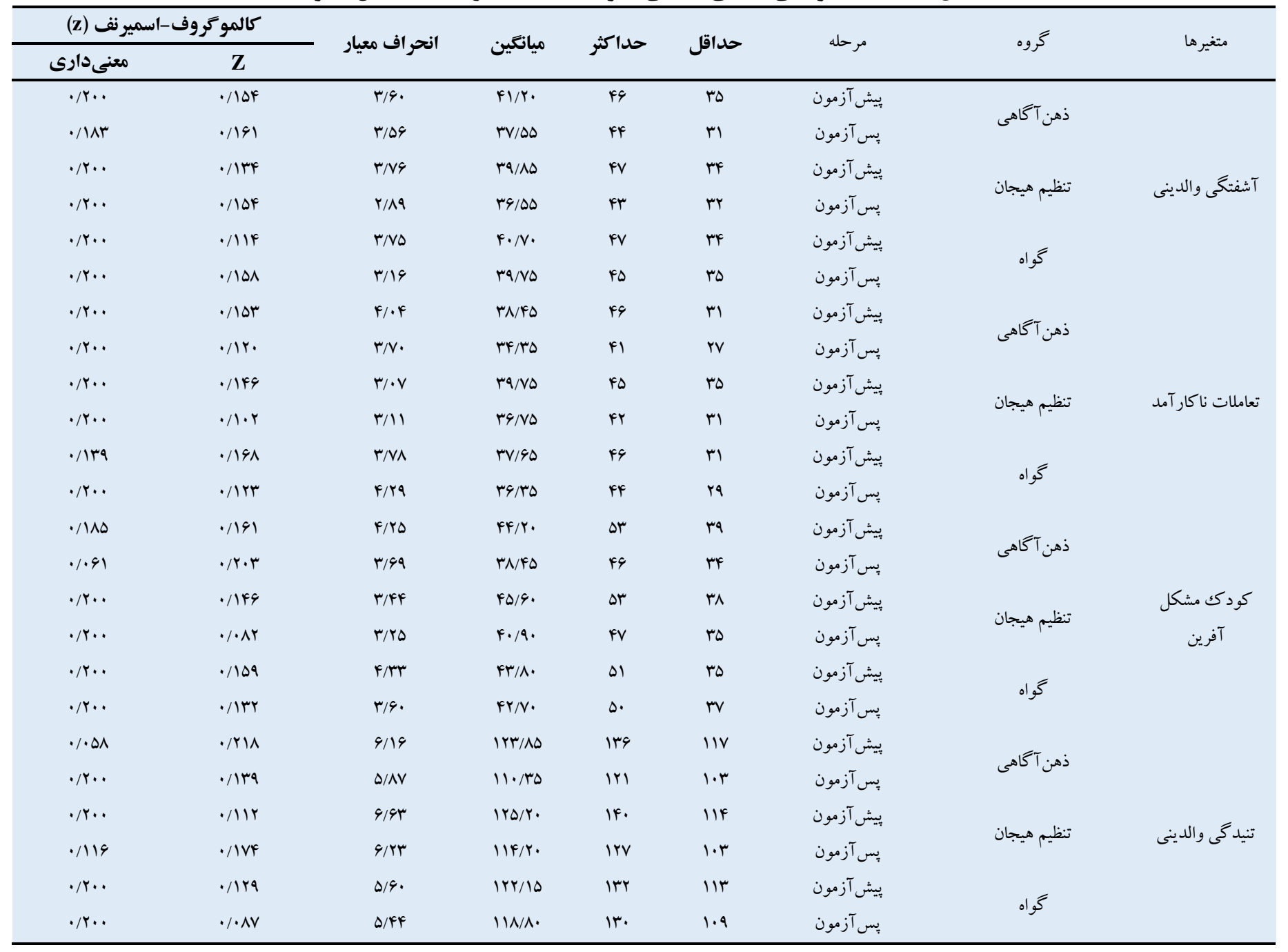

آزمون ام باكس استفاده شد كه نتايج اين آزمون به علت وجود هم خطى

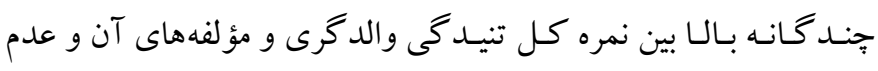

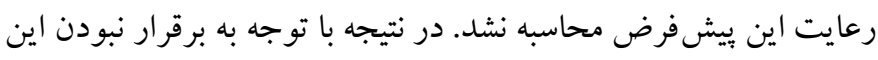

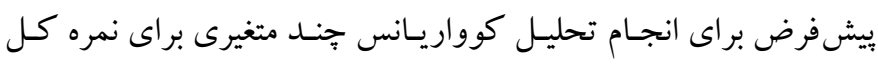

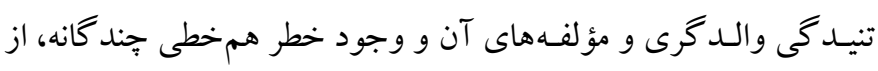

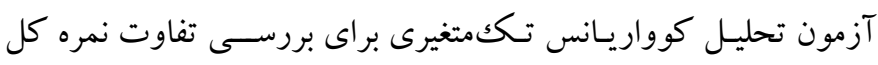

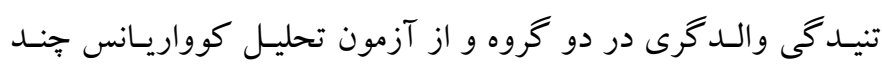

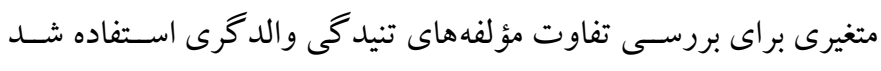

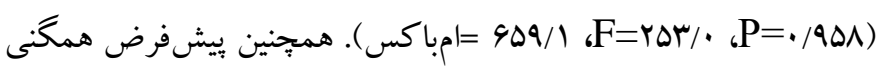

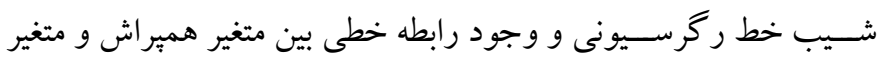

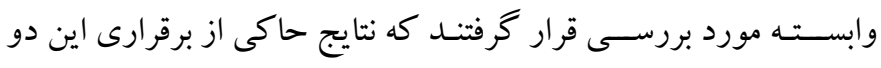

براسـاس اطلاعات به دست آمده در جدول، ميانگين و انحر اف معيار

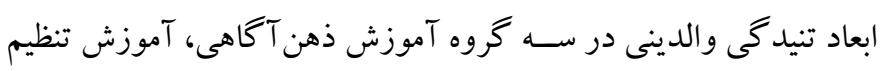

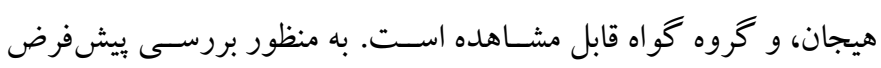

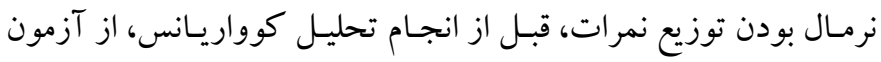

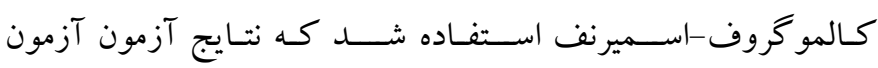
كالمو گروف-اسـميرنف حاكى از اين بود كه توزيع داده ها براى ابعاد

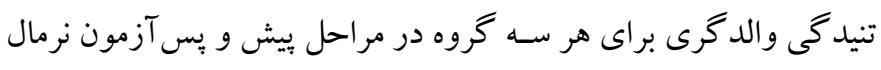

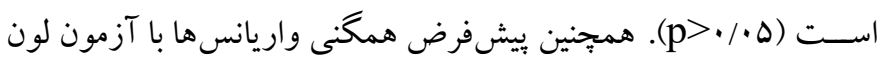

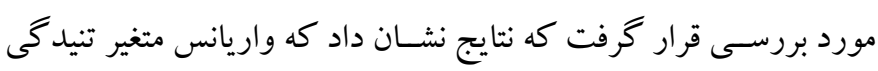

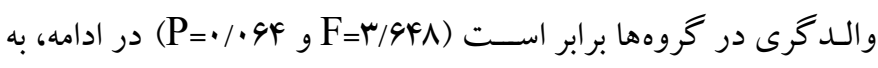
منظور بررسسى ييش فرض همخنى ماتريس هاى واريانس -كوواريانس از 


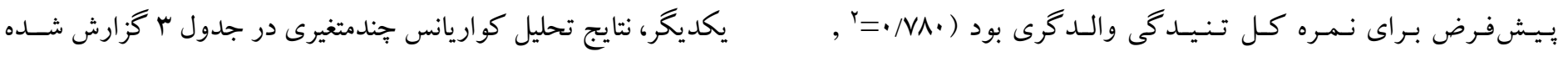

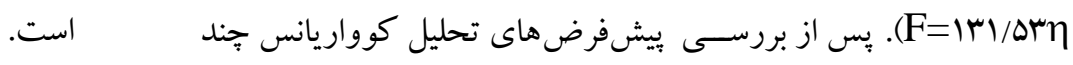

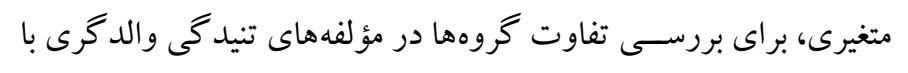

جدول (ז) نتايج تحليل كواريانس اثرات بين كروهى ميانعين ابعاد تنيد

\begin{tabular}{|c|c|c|c|c|c|c|c|}
\hline ضريب اتا & سطح معنادارى & $\mathbf{F}$ & ميانكين مجذورات & درجه آزادى & مجموع مجذورات & منبع تغييرات & مؤلفهها \\
\hline.$/ \cdot 9$ & $\cdot / 1 \cdot 0$ & $r / r \Delta$ & $4 / 49$ & $r$ & $\Lambda / V r$ & 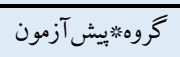 & \\
\hline \multirow[t]{2}{*}{ - MFFr } & $\cdot / \cdots 1$ & rI/ro & Fr/qr & r & $\wedge \Delta / \wedge \vee$ & كروه & آشفتگى والدينى \\
\hline & & & $r / \cdot 1 \cdot$ & $\Delta F$ & $1 \cdot N / \Delta 9$ & خطا & \\
\hline.$/ \cdot 18$ & .1999 & $\cdot / 4 \cdot \Delta$ &.$/ 9 \mathrm{YV}$ & r & $1 / r \Delta$ & گروهّ"يش آزمون & \\
\hline \multirow[t]{2}{*}{$\cdot / k v r$} & $\cdot / \cdots 1$ & $Y F / Y G$ & $r V / V r$ & r & $V Q / F V$ & كروه & تعاملات ناكار آمد \\
\hline & & & $1 / \Delta \Delta$ & $\Delta F$ & $\wedge r / 99$ & خطا & \\
\hline.$/ .4$ & . TYSO & 1/هr & $r / .4$ & r & $f / l r$ & گروه॰* بيش آزمون & \\
\hline \multirow[t]{2}{*}{ - MFr } & $\cdot / \cdots 1$ & WV/VY & $11 \cdot / 91$ & r & YrI/Al & كروه & كودكك مشكل آفرين \\
\hline & & & I/FYV & $\Delta F$ & $\mathrm{VW} / .91$ & خطا & \\
\hline
\end{tabular}

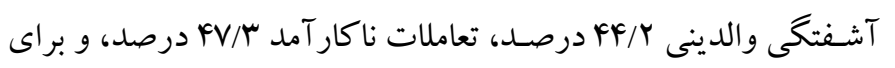

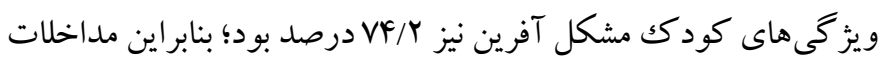

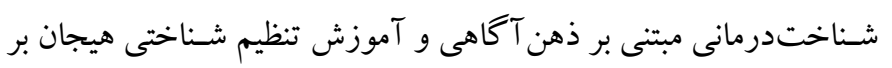

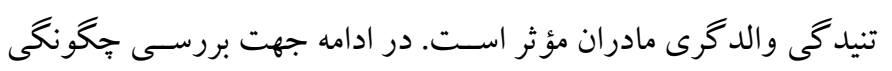

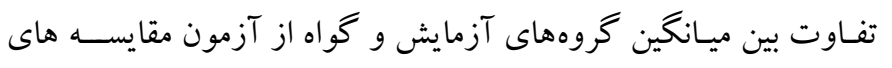
زوجى HSD استفاده شد كه نتايج آن در جدول بأب ارائه شده است.
نتـايج جـدول ب نشــان مى دهـد مداخلات شــناخت درمانى مبتنى بر

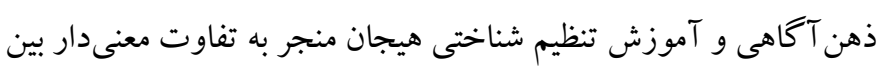

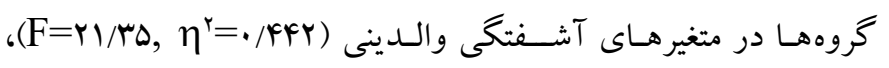

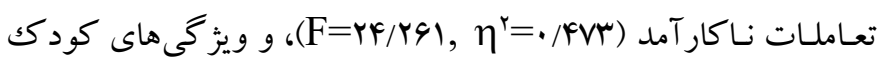

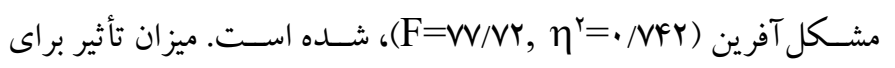

جدول ع: نتايج آزمون تعقيبىHSD جهت مقايسه زوجى ميانكين تنيدكى والدكرى در كروهها

\begin{tabular}{|c|c|c|c|c|c|}
\hline معنادارى & خطاى استاندارد & تفاوت ميانكين & \multicolumn{2}{|c|}{ كروه } & متغير \\
\hline.$/ 9 Y 9$ &.$/ 491$ & $-\cdot /+41$ & ت تظيم هيجان & ذهن آكاهى & \\
\hline$\cdot \cdots 1$ & - $/ A \Delta r$ & $-r / 919^{*}$ & كواه & ذهن آكاهى & آشفتخى والدينى \\
\hline$* \ldots 1$ &.$/ 491$ & $r / \Delta V \Lambda^{\circ}$ & كواه & تنظيم هيجان & \\
\hline$\%$ & $\cdot / 4 \cdot \Delta$ & $-1 / Y F_{0}$ & ت تظيم هيجان & ذهن آكاهى & \\
\hline$* \ldots 1$ & $\cdot /$ rav & $-r / V 9 V^{*}$ & كواه & ذهن آكاهى & تعاملات ناكار آمد \\
\hline$\cdot / \cdots 1$ & . & $-1 / 0$ Y & كواه & تنظيم هيجان & \\
\hline$\%$ & $\cdot \pi M$ & $-1 / Y Y^{*}$ & تنظيم هيجان & ذهن آكاهى & \\
\hline$\cdot \cdots 1$ & . & $-F / 91 F^{\circ}$ & كواه & ذهن آكاهى & كودكك مشكل آفرين \\
\hline$\cdot \cdots 1$ & . rap & $-r / r \wedge g^{*}$ & كواه & تنظيم هيجان & \\
\hline
\end{tabular}

ذهن آكَاهى، آموزش تنظيم هيجـانى، و گو اه بـه نفع ميانگين خروههاى

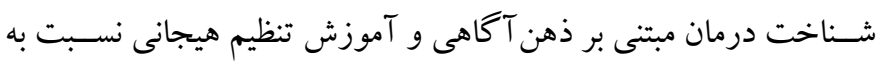

نتايج مربوط به آزمون HSD در جدول \& نشان مىدهد كه در مؤلفه

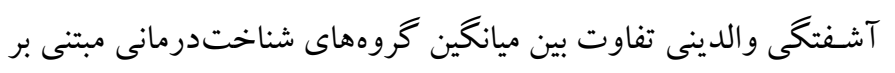


است و به تبع آن احساس افسردگى و فقدان شايستگى كه مبين احساس

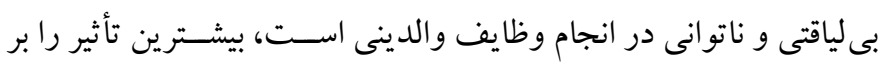

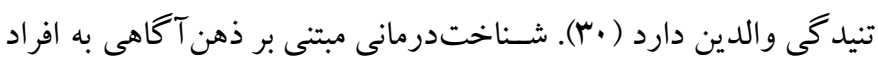

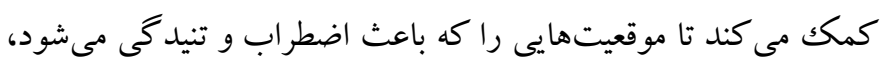

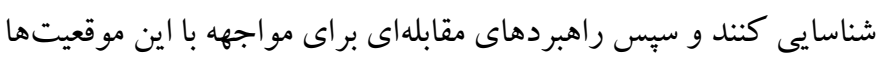

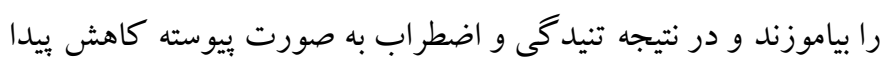

كند (YV).

نتايج همجنين نشـان داد كه در مؤلفه آشـفتخى والدينى، تفاوت بين

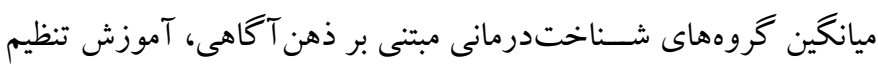

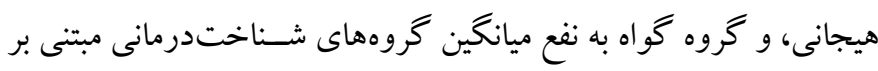

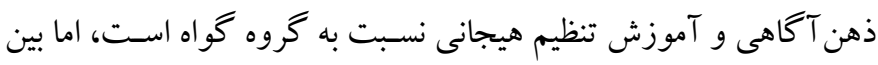

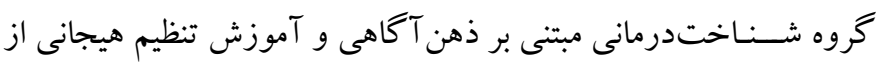

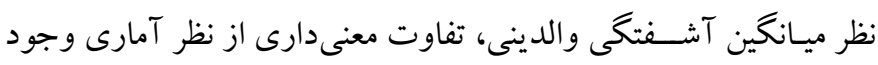

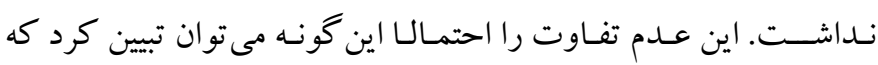
شــاخت درمانى مبتنى بر ذهن آكاهى باعث ارتقاى خود آكاهى مادران،

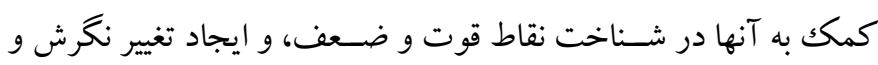
باورهايشـان مىشــود (YN). به اين ترتيب كه مادران در خلال جلسـات

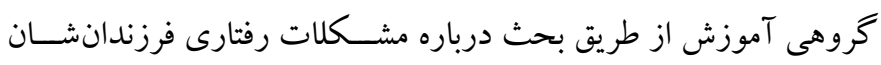
درمى يـابند كه بسـيارى از اين مشــكلات رفتارى در بين تمامى والدين حاضر مشتر كك و مشابه است. در نتيجه از ميزان احساس عدم صلاحيت و

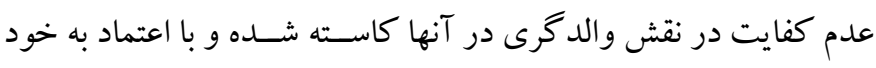

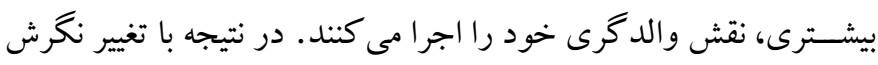

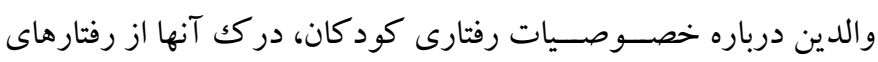

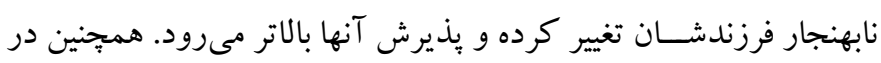

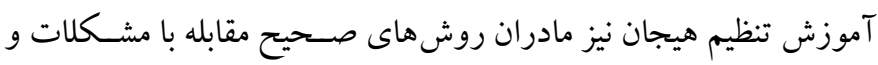

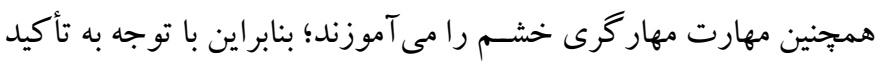

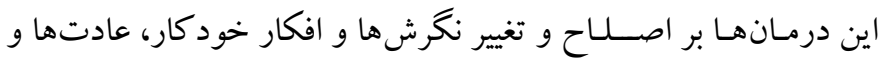
الكوهاى رفتارى ناسالم، عدم تفاوت بين دو درمان قابل توجيه است.

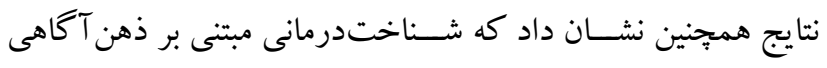

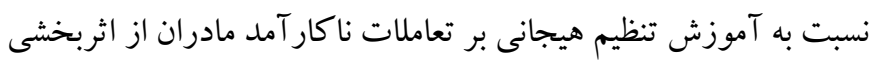

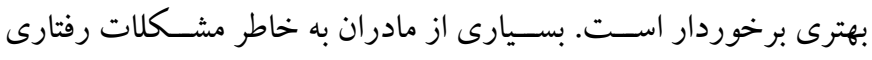

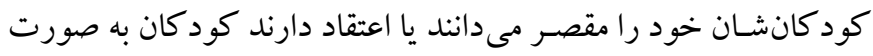

كروه گواه اسـت؛ اما بين گروه شــاختدرمانى مبتنى بر ذهن آكاهى و

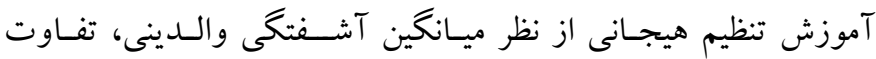

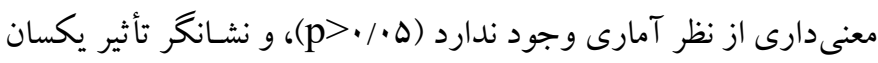
شناختدرمانى مبتنى بر ذهن آكاهى و آموزش تنظيم هيجانى بر آشفتكى آنى

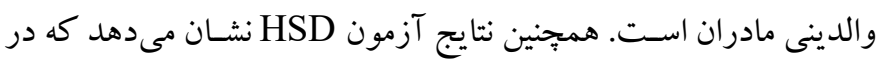

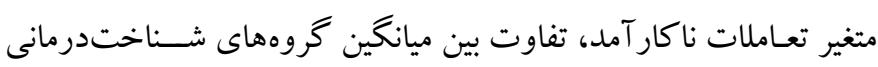

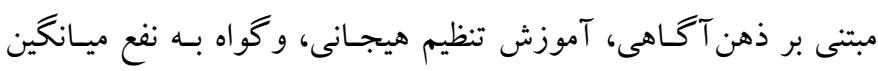

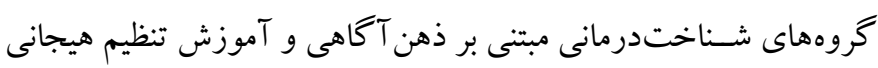

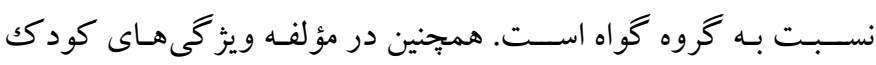

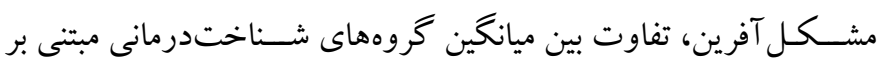

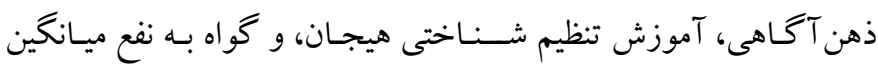

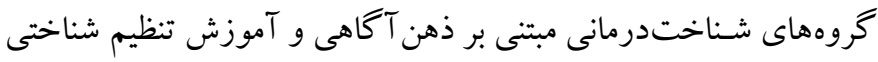

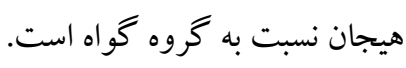

بحث و نتيجه تيرى

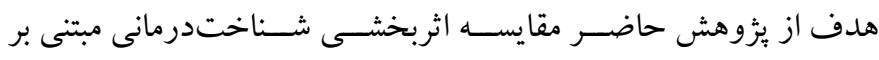

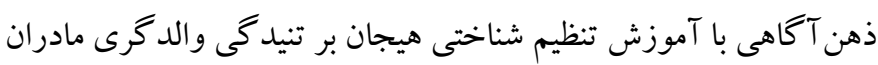

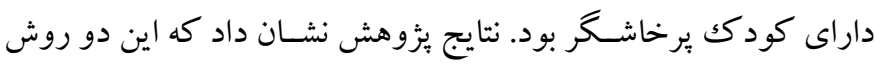

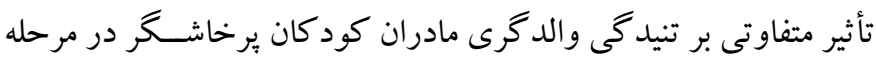

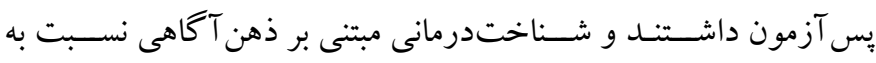

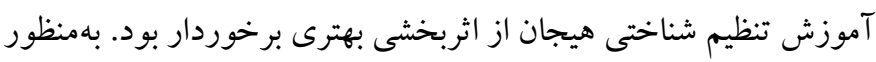

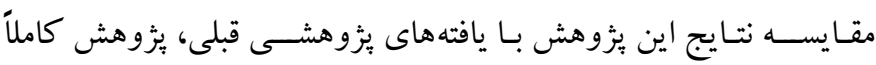

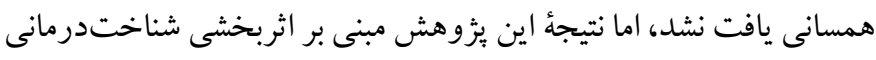

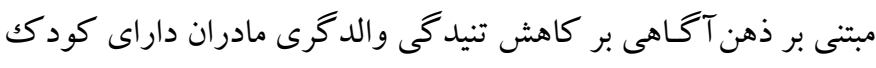

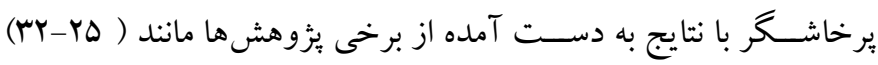

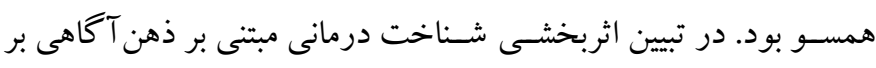

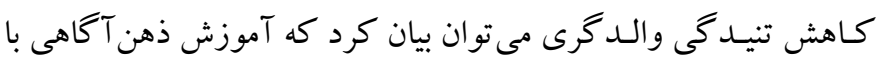
بازنمايى ذهنى اشيا موجود در زندگى كه از كنترل بلافاصله انسان خارج

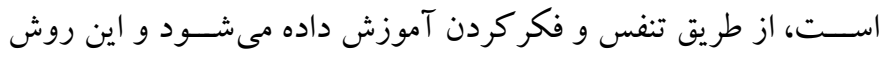
درمانى موجـب ايجاد ســلامت روان و كاهش باورهاى غلط در مادران

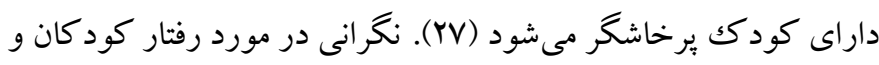

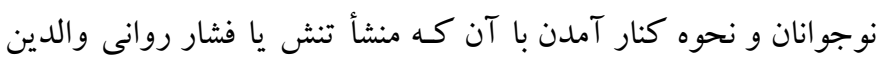


نتايج يزوهش همجينين نشـان داد آموزش تنظيم شــناختى هيجان بر

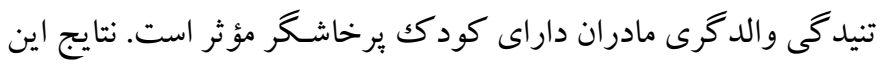

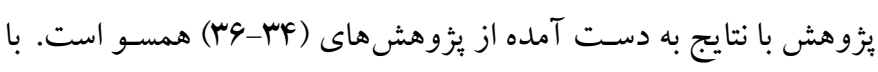
آموزش تنظيم هيجان، مادر روش هاى صسحيح مقابله با مشـكلات، نحون دهوه

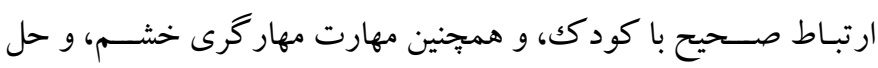

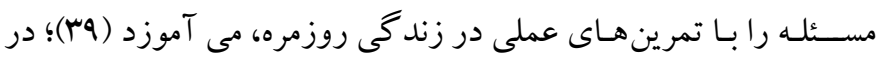

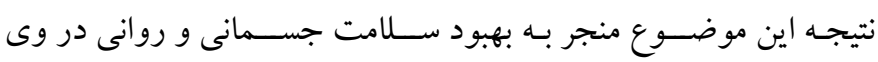
مىشود. در تبيين اثربخشى بالاتر شناخت درمانى مبتنى بر ذهن آكاهى نسبت به

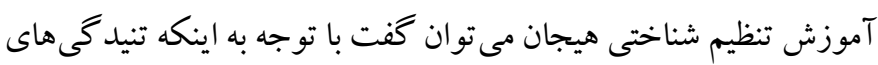

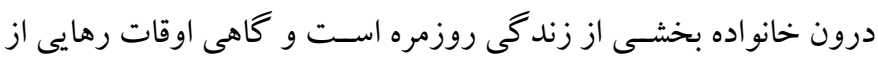

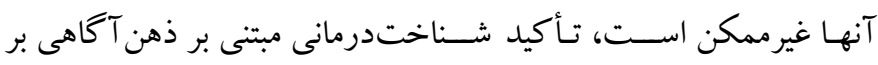

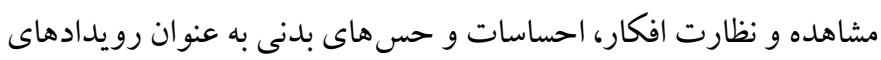

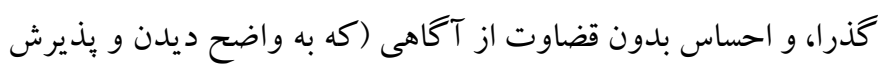

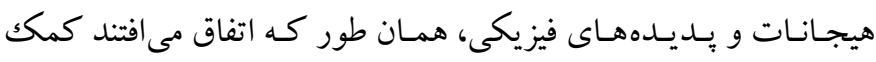

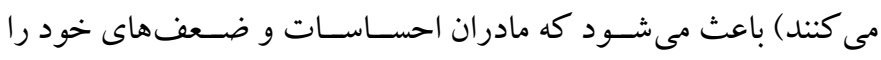
بيذيرند و قبول و بذيرش اين احسـاسات باعث كاهش توجه و حساسيت

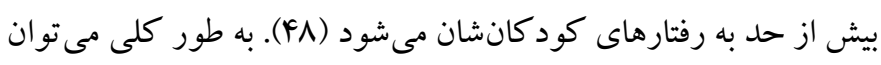

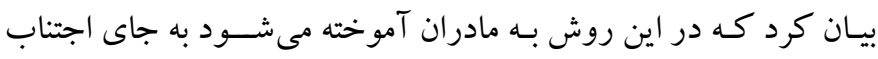

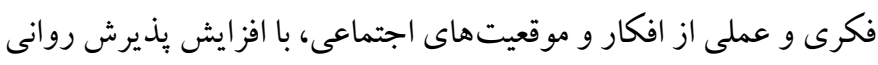

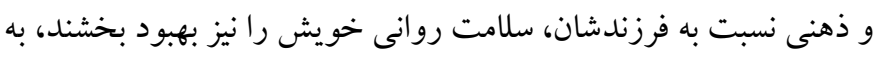
ارزش هاى شـخصى خود برسـند، و مشـكل ها را از سر راه خود برد بردارند

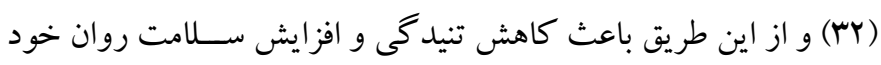

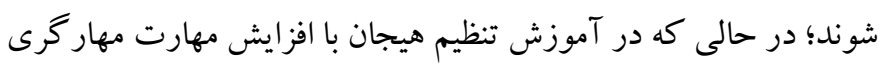

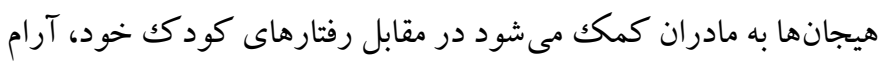

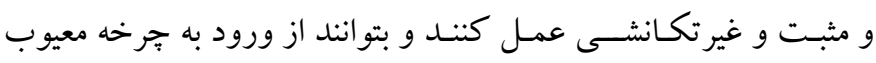

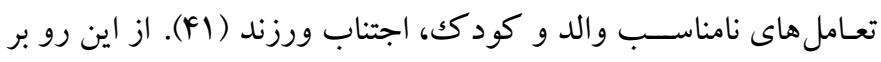
اسـاس نتايج اين مطالعه، شــناختدرمانى مبتنى بر ذهن آكاهى به عنو أنوان

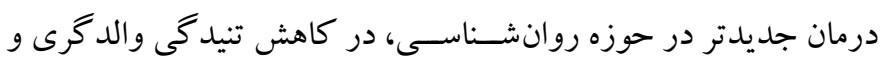

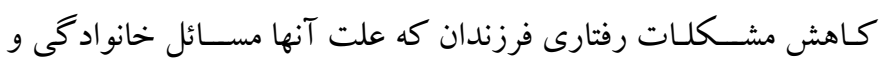
شيوههاى والدگرى است، مى تواند مؤثر واقع شود.
ارادى راهى را براى اذيـت و آزار آنها انتخاب كردهاند. در ذهن آكاهى

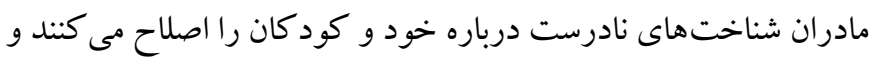

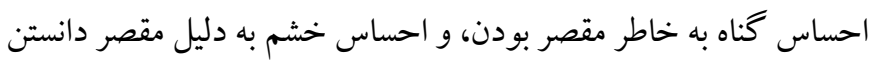

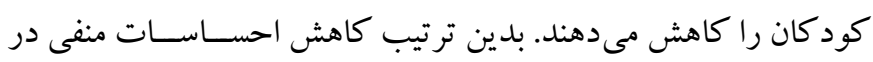

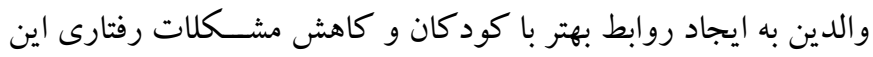

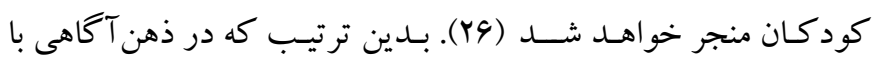

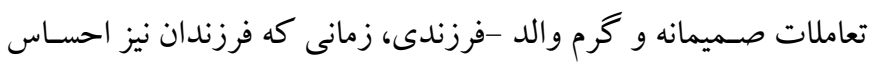

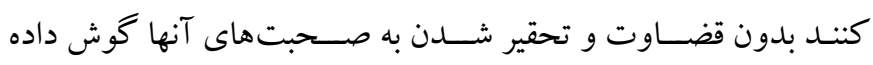

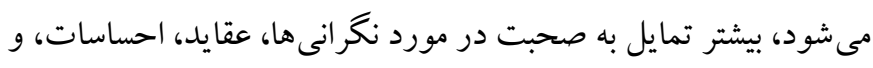

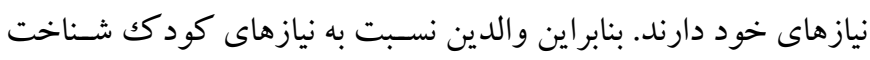

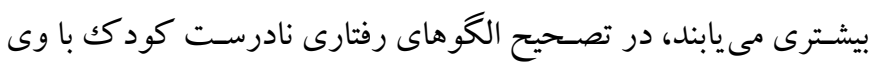

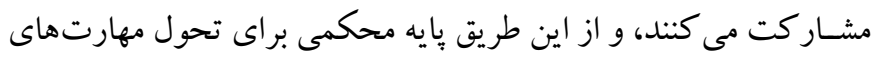

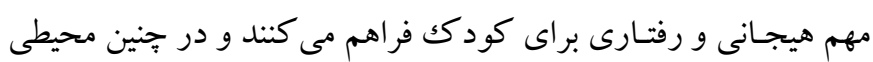

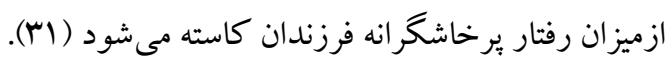

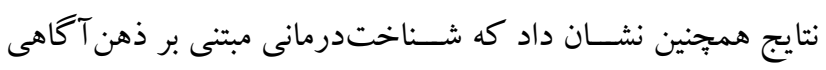

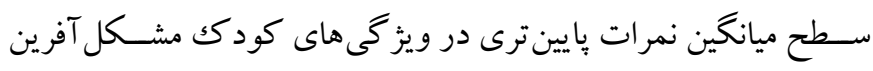

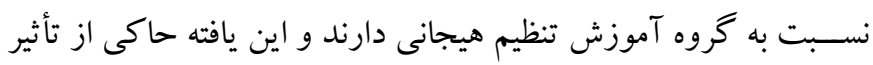

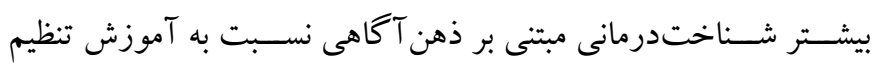

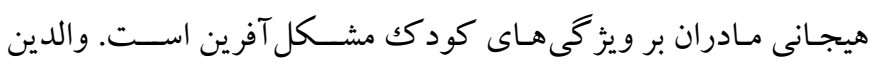

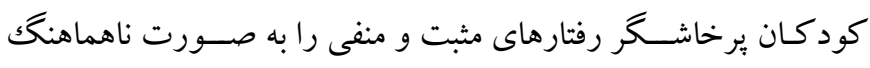

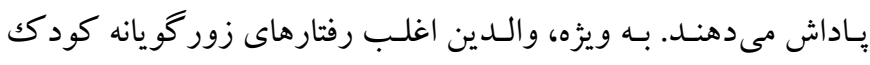

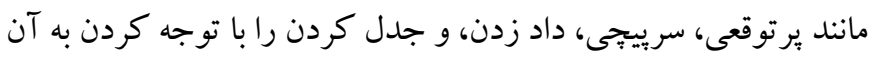

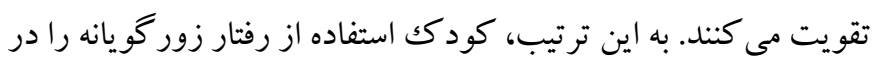

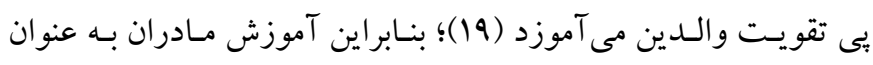

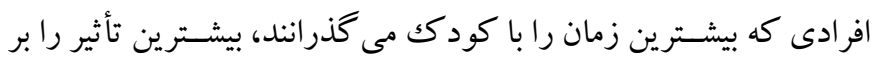

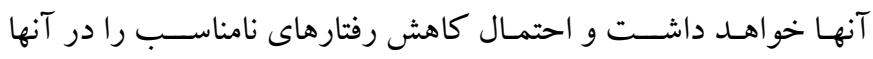
افزايش خو اهد داد. مادران در برنامه شناختدرمانى مبتنى بر ذهن آكاهى آنى

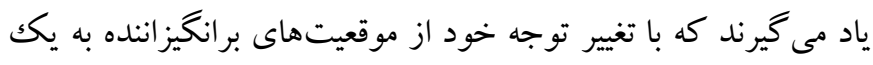

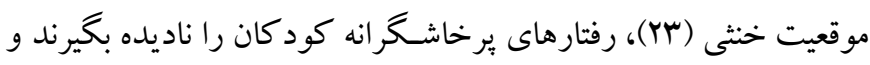
به اين ترتيب احتمالاً راهبردهاى مقابلهاى سازش يافته ترى را جهت مقائ مقابله با اين موقعيتها، يرورش دهند. 
قرار گيرد تا نتايج بيشگير انه بهترى به همراه داشته باشد. همخنين مدرسان

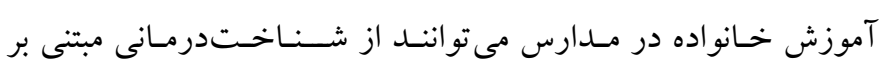

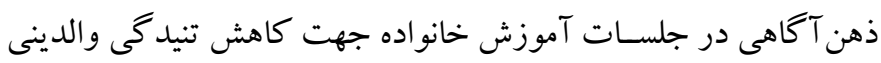

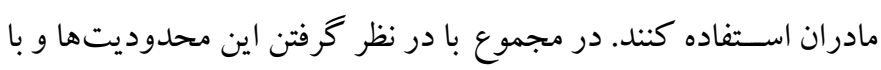

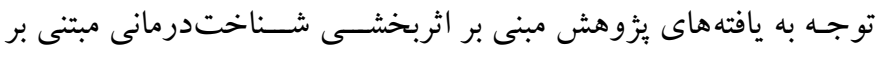

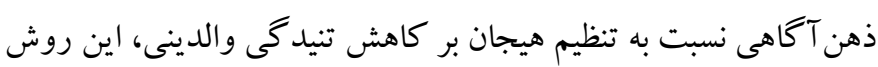

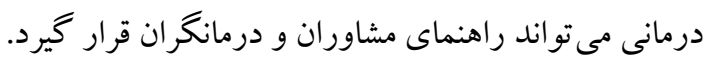

تشكر و قدردانى: اين مقاله بركرفته از رسـاله دكتراى تخصصى خانم افسانه

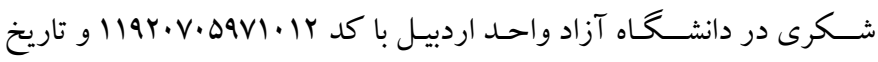

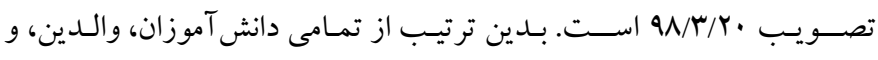

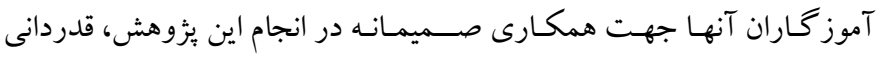
مىشود. تضاد منافع: انجام اين بثروش هيج گونه تضاد منافع را براى نويسند كان به دنبال نداشته است.
عـدم انجـام مرحلـه بيخيرى، تقويت اثر هالهاى مربوط به يكى بودن

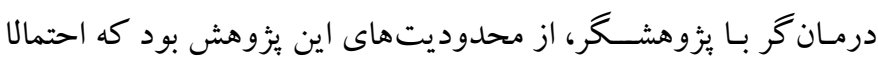

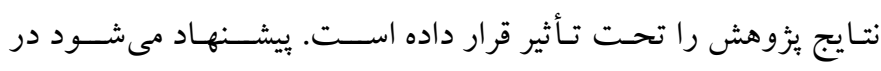

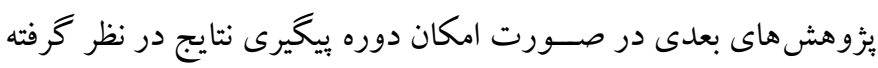

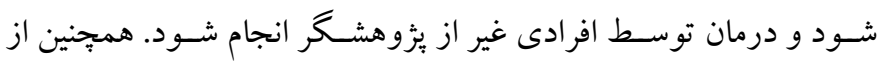

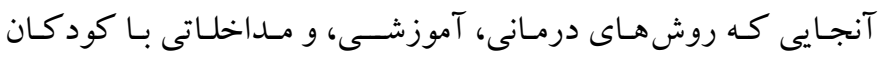

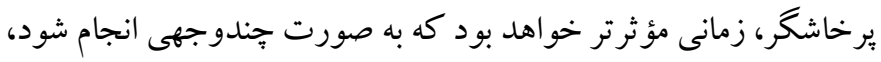

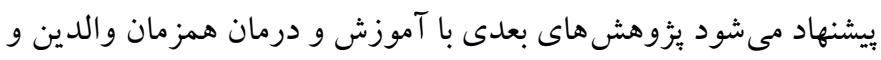

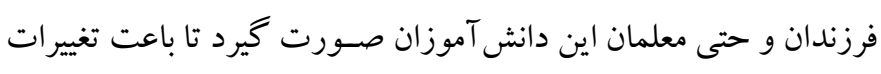

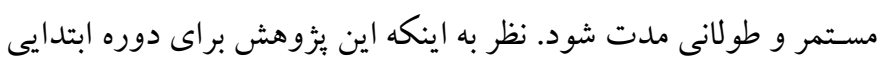

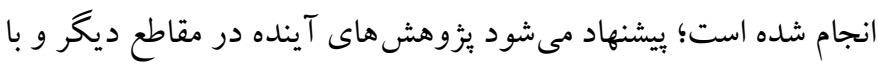

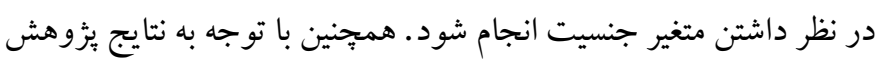

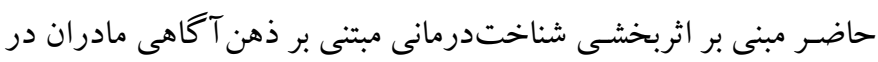

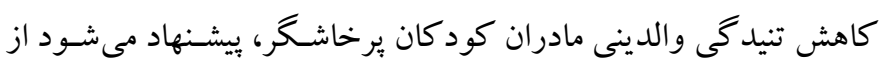
اين درمان در كاهش تنش هاى خانو ادمى قبل از دبسـتان مورد اسـتفاده 


\section{References}

1. Akbari B, Rahmati F. The efficacy of cognitive behavioral play therapy on the reduction of aggression in preschool children with attention deficit/hyperactivity disorder. Quarterly Journal of Child Mental Health. 2015; 2(2): 93-100. [Persian]. [Link]

2. Moridian S, Goodarzy K, Rozbahani M. Determining the effectiveness of game therapy on children's aggression, stress and anxiety. Journal of Motor and Behavioral Sciences. 2019; 2(2): 116-125. [Persian]. [Link]

3. Mohammadi M, Vaisi Raiegani A A, Jalali R, Ghobadi A, Abbasi P. Prevalence of Behavioral Disorders in Iranian Children. J Mazandaran Univ Med Sci. 2019; 28 (169) :181-191. [Persian]. [Link]

4. Cooper P. Evidence based approaches to mental health issues in schools. In: Cefai C, Cooper P, editors. Mental health promotion in schools: Cross-cultural narratives and perspectives. Rotterdam: SensePublishers; 2017, pp: 11-21. [Link]

5. Fitzpatrick SE, Srivorakiat L, Wink LK, Pedapati EV, Erickson CA. Aggression in autism spectrum disorder: presentation and treatment options. Neuropsychiatr Dis Treat. 2016; 12: 1525-1538. [Link]

6. Ehrenreich SE, Beron KJ, Brinkley DY, Underwood MK. Family predictors of continuity and change in social and physical aggression from ages 9-18. Aggressive Behav. 2014; 40(5): 421-439. [Link]

7. Riahi F, Amini F, Salehi Veisi M. The children's behavioral problems and their relationship with maternal mental health. Journal of Jahrom University of Medical Sciences. 2012; 10(1): 46-52. [Persian]. [Link]

8. Pourvahed A, Amiri-Majd M. The relationship between maternal mental health problems and domestic violence with mentally retarded children behavioral problems. Salamat Ijtimai (Community Health). 2017; 4(2): 110-117. [Persian]. [Link]

9. Hoyo-Bilbao JD, Gámez-Guadix M, Calvete E. Corporal punishment by parents and child-to-parent aggression in Spanish adolescents. Anales de Psicología / Annals of Psychology. 2017; 34(1), 108116. [Link]

10. Shafiee S, Hashemirazini H, Shahgholian M. The role of parent-child interaction and sensory processing pattern in predicting children's internalizing and externalizing problems. Journal of Exceptional Children. 2018; 18(1): 19-32. [Persian]. [Link]
11. Abidin RR. Parenting stress index: Professional manual. 3rd ed. Odessa, Fla.: Psychological Assessment Resources; 1995. [Link]

12. Xuan X, Chen F, Yuan C, Zhang X, Luo Y, Xue Y, et al. The relationship between parental conflict and preschool children's behavior problems: A moderated mediation model of parenting stress and child emotionality. Child Youth Serv Rev. 2018; 95(C): 209-216. [Link]

13. Zhou N, Cao H, Leerkes EM. Interparental conflict and infants' behavior problems: The mediating role of maternal sensitivity. J Fam Psychol. 2017; 31(4): 464474. [Link]

14. Di Blasio P, Camisasca E, Miragoli S, Ionio C, Milani L. Does maternal parenting stress mediate the association between postpartum pts symptoms and children's internalizing and externalizing problems? A longitudinal perspective. Child Youth Care Forum. 2017; 46(5): 685-701. [Link]

15. Gabler S, Kungl M, Bovenschen I, Lang K, Zimmermann J, Nowacki K, et al. Predictors of foster parents' stress and associations to sensitivity in the first year after placement. Child Abuse Negl. 2018; 79:325-338. [Link] .

16. Wong RSM, Yu EYT, Guo VY, Wan EY-F, Chin W$\mathrm{Y}$, Wong $\mathrm{CKH}$, et al. A prospective cohort study to investigate parental stress and child health in lowincome Chinese families: Protocol paper. BMJ Open. 2018; 8(2): e018792. [Link]

17. Dardas LA, Ahmad MM. For fathers raising children with autism, do coping strategies mediate or moderate the relationship between parenting stress and quality of life? Res Dev Disabil. 2015; 36: 620-629. [Link]

18. Kheiri H, Salehi I, Soltani Shal R. Effects of cognitive-behavioral stress management training on mothers' quality of life and their children's behavioral problems. Quarterly Journal of Family and Research. 2019; 15(4): 7-26. [Persian]. [Link]

19. Ershad Sarabi R, Hashemi Razini H, Abdollahi MH. Comparing parental stress, parenting styles, and social problem solving in mothers of children with autism spectrum disorder, ADHD, and typically developing children. Quarterly Journal of Child Mental Health. 2018; 4(4): 165-179. [Persian]. [Link]

20. Miragoli S, Balzarotti S, Camisasca E, Di Blasio P. Parents' perception of child behavior, parenting stress, and child abuse potential: Individual and partner influences. Child Abuse Negl. 2018; 84:146-156 [Link]

21. Sharifi- Shaki S, Aakhte M, Alipor A, Fahimi-Far A, Taghadosi M, Karimi R, et al. The effectiveness of 
mindfulness-based cognitive therapy in reducing anxiety and meta-worry in women with recurrent miscarriages. KAUMS Journal (FEYZ). 2015; 19(4): 334-340. [Persian]. [Link]

22. Jonsdottir S. Effectiveness of mindfulness based cognitive therapy compaired to physical exercise as a follow-up treatment to prevent depressive relapse and maintain recovery [BSc thesis]. [Reykjavík, Iceland]: Department of psychology school of business, Reykjavik University; 2016, pp: 1-43. [Link]

23. Bailie C, Kuyken W, Sonnenberg S. The experiences of parents in mindfulness-based cognitive therapy. Clin Child Psychol Psychiatry. 2012; 17(1): 103-119. [Link]

24. Segal ZV, Williams JMG, Teasdale JD. Mindfulnessbased cognitive therapy for depression: A new approach to preventing relapse. New York, NY, US: Guilford Press; 2002, p: 351. [Link]

25. Aghdasi N, Soleimanian A A, Asadi Gandomani R. The effectiveness of mindfulness training on emotional schemas mothers of children with cerebral palsy. Archives of Rehabilitation. 2019; 20 (1):86-97. [Persian]. [Link]

26. Chaplin TM, Turpyn CC, Fischer S, Martelli AM, Ross CE, Leichtweis RN, et al. Parenting-focused mindfulness intervention reduces stress and improves parenting in highly stressed mothers of adolescents. Mindfulness. Published: 21 September 2018. Available from: [Link]

27. Rayan A, Ahmad M. Mindfulness and parenting distress among parents of children with disabilities: A literature review. Perspect Psychiatr Care. 2018; 54(2), 324-330. [Link]

28. Bazzano A, Wolfe C, Zylowska L, Wang S, Schuster $\mathrm{E}$, Barrett C, et al. Mindfulness based stress reduction (MBSR) for parents and caregivers of individuals with developmental disabilities: A community-based approach. J Child Fam Stud. 2015; 24(2): 298-308. [Link]

29. Mehri Nejad S, Ramezan Saatchi L. Impact of mindfulness-based cognitive therapy on depression, anger and emotion regulation of veterans' spouses. Iran J War Public Health. 2016; 8 (3):141-148. [Persian]. [Link]

30. Gadampour E, Moradizadeh S, Shakarami M. The study of effectiveness of training of mind consciousness on reduction of the elderly's feeling of loneliness and death anxiety in Sedigh center of
Khoramabad city. Razi Journal of Medical Sciences. 2019; 26(4): 44-53. [Persian]. [Link]

31. Khodabakhshi Koolaee A, Shahi A, Navidian A, Mosalanejad L. The effect of positive parenting program training in mothers of children with attention deficit hyperactivity on reducing children's externalizing behavior problems. Journal of Fundamentals of Mental Health. 2015; 17(3): 135141. [Persian]. [Link]

32. Valipour M, Hosseinian S, Pourshahriari M. The effectiveness of cognitive therapy based on mindfulness on children's behavioral problems. Quarterly Journal of Child Mental Health. 2018; 4 (4):34-45. [Persian]. [Link]

33. Mohammadi M, Tahmassian K, Ghanbari S, Fathabadi, J. Comparison of the effectiveness of mindful parenting training with adolescent mindfulness-based cognitive therapy on reducing parental stress and parent-adolescent conflict [Master thesis]. [Tehran, Iran]: Family Research Institute, Shahid Beheshti University; 2018. [Persian].

34. Beyrami M, Hashemi T, Bakhshi Pour A, Mahmoud Alilo M, Eghbali A. Comparison the effect of two methods of cognitive emotion regulation training and mindfulness-based cognitive therapy on psychological distress and cognitive emotion regulation strategies of mothers of mentally retarded children. Journal of Modern Psychological Researches. 2014; 9(33): 43-59. [Persian]. [Link]

35. Verzeletti C, Zammuner VL, Galli C, Agnoli S. Emotion regulation strategies and psychosocial wellbeing in adolescence. Cogent Psychol. 2016; 3(1): 1199294. [Link]

36. Mahdavi A, Pahlevani M, Aghaei M, Aminnasab V, Haji H, Gholamrezaei S. Relationship of strategies for emotion cognitive adjustment with psychological well-being and anxiety in mothers with cancer children. Annals of Tropical Medicine and Public Health. 2017; 10(3): 702-706. [Link]

37. Gross JJ. Emotion regulation: Affective, cognitive, and social consequences. Psychophysiology. 2002; 39(3):281-91. [Link]

38. Chew BH, Zain AM, Hassan F. Emotional intelligence and academic performance in first and final year medical students: A cross-sectional study. BMC Med Educ. 2013; 13(1): 44. [Link]

39. Gowdini R, Pourmohamdreza-Tajrishi M, Tahmasebi S, Biglarian A. Effect of emotion management training to mothers on the behavioral problems of offspring: Parents' view. Archives of Rehabilitation. 2017; 18(1): 13-24. [Persian]. [Link] 
40. Quetsch LB, Wallace NM, McNeil CB, Gentzler AL. Emotion regulation in families of children with behavior problems and nonclinical comparisons. J Child Fam Stud. 2018; 27(8): 2467-2480. [Link]

41. Waters SF, Virmani EA, Thompson RA, Meyer S, Raikes HA, Jochem R. Emotion regulation and attachment: unpacking two constructs and their association. J Psychopathol Behav Assess. 2010; 32(1):37-47. [Link]

42. Leff SS, Crick NR. Interventions for relational aggression: innovative programming and next steps in research and practice. School Psych Rev. 2010; 39(4): 504-507. [Link]

43. Ahmadi Z, Asaran M, Seyyedmoharrami F, Seyyedmoharrami I. The relationship between overt and relational aggression with hope in primary school children. Quarterly Journal of Child Mental Health. 2017; 4(3): 143-152. [Persian]. [Link]

44. Shahim S. Relational aggression in preschool children. Iranian Journal of Psychiatry and Clinical Psychology. 2007; 13(3): 264-271. [Persian]. [Link]
45. Fadaei Z, Dehghani M, Farhadei F, Tahmasian K. Investigating reliability, validity and factor structure of parenting stress- short form in mother's of 7-12 year-old children. Journal of Research in Behavioural Sciences. 2010: 8(2); 81-91. [Persian]. [Link]

46. Kaveh M, Alizadeh H, Delavar A, Borjali A. Development of a resilience fostering program against stress and its impact on quality of life components in parents of children with mild intellectual disability. Journal of Exceptional Children. 2011; 11(2): 119140. [Persian]. [Link]

47. Hillgaar SD. Mindfulness and self regulated learning [Master's thesis]. [Trondheim, Norway]: Department of Psychology, Norwegian University of Science and Technology (NTNU); 2011, 1-85, [Link]

48. Mohammadkhani P, Khanipoor H. Therapies based on mindfulness. Tehran: Publication of Well-being and Rehabilitation University; 2005. [Persian].

49. Gross JJ. Emotion regulation: Conceptual and empirical foundations. In: Gross JJ, editor. Handbook of emotion regulation. 2nd Ed. New York, NY, US: Guilford Press; 2014, pp: 3-20. [Link] 